\title{
THE IMPACT OF THE ESTATE TAX ON THE WEALTH ACCUMULATION AND AVOIDANCE BEHAVIOR OF DONORS
}

\author{
Wojciech Kopczuk \\ Joel Slemrod \\ Working Paper 7960 \\ http://www.nber.org/papers/w7960 \\ NATIONAL BUREAU OF ECONOMIC RESEARCH \\ 1050 Massachusetts Avenue \\ Cambridge, MA 02138 \\ October 2000
}

We are grateful to the Statistics of Income Division of the Internal Revenue Service for allowing access to confidential estate tax return data under a data disclosure agreement. We especially thank Barry Johnson of SOI for patiently explaining the data structure and facilitating our analysis. Rob Greebel and Cassie Stone provided assistance on the history of estate tax provisions. Alan Auerbach, Julie Cullen, Bill Gale, David Joulfaian, and the participants at the conference Rethinking Estate and Gift Taxation provided helpful comments on an earlier draft. The views expressed in this paper are those of the authors and not necessarily those of the National Bureau of Economic Research.

(C) 2000 by Wojciech Kopczuk and Joel Slemrod. All rights reserved. Short sections of text, not to exceed two paragraphs, may be quoted without explicit permission provided that full credit, including $(\mathrm{C}$ notice, is given to the source. 
The Impact of the Estate Tax on the Wealth Accumulation and Avoidance Behavior of Donors

Wojciech Kopczuk and Joel Slemrod

NBER Working Paper No. 7960

October 2000

JEL No. H2, H3

\section{$\underline{\text { ABSTRACT }}$}

Using estate tax return data from 1916 to 1996, we investigate the impact of the estate tax on reported estates, which reflects the impact of the tax on both wealth accumulation and avoidance. An aggregate measure of reported estates is generally negatively correlated with summary measures of the level of estate taxation, holding constant other influences. In pooled cross-sectional analysis that makes use of individual decedent information, the relationship between the concurrent tax rate and the reported estate is fragile and sensitive to the set of instruments that are used to capture exogenous tax rate variation. However, the negative effect of taxes appears to be stronger for those who die at a more advanced age and with a will, both of which are consistent with the theory of how estate taxes affect altruistic individuals. Finally, we find that the tax rate that prevailed at age 45 or ten years before death is more clearly (negatively) associated with reported estates than the tax rate prevailing at death. Future research should concentrate on developing lifetime measures of the effective tax rates and on better measurements of the effective tax rate for married couples.

Joel Slemrod

University of Michigan Business School

701 Tappan Street, Rm. A2120

Ann Arbor, MI 48109-1234

and NBER

jslemrod@umich.edu
Wojciech Kopczuk

Department of Economics

University of Michigan

611 Tappan

Ann Arbor, MI 48109 


\section{Introduction}

Whether an estate tax deserves a role in the U.S. tax system depends in part on its impact on the behavior of potential donors. Opponents of the estate tax argue that it reduces the incentive to accumulate wealth in two ways: by reducing the incentive to earn income, and by increasing the incentive to consume. Supporters tend to downplay the salience of these incentives, and often ascribe wealth accumulation to motives that are immune to taxation. For example, Sandford (1984, p. 226) writes that "Much saving is undertaken with no thought of bequests in mind; people accumulate property for a variety of reasons - future security and enjoyment; the power that wealth confers; inertia - the sheer inability to spend their wealth; the desire to manage a large business; the posthumous glory of dying rich; and many others which are unaffected by death duty considerations." Opponents of the estate tax also refer to the magnitude of avoidance it engenders. For example, the U.S. Joint Economic Committee report asserts that "Virtually any individual who invests sufficient time, energy and money in tax avoidance strategies is capable of avoiding the estate tax altogether" (1998, p. 20). Both the impact on wealth accumulation and the "time, energy, and money" devoted to avoidance should be counted as costs of levying the estate tax, to be weighed against the revenue it raises in a highly progressive manner.

Although assertions about the impact of the estate tax are made with great confidence, there is almost no empirical evidence to support either claims of a large effect or of a negligible effect. In this paper we begin an empirical analysis of this issue, and proceed as follows. In section 2, we consider theoretically the question of the impact of an estate tax on the behavior of a prospective donor. Section 3 discusses the existing empirical literature. We then turn to an empirical investigation of the impact of the estate tax. In section 4 we examine the effect of an estate tax on reported estates in a time-series context, using aggregated data from estate tax raturns that span 1916 to 1996. In section 5 we make use of individual tax return data to extend that analysis. Section 6 concludes. 


\section{Models of How the Estate Tax Affects Potential Donors' Behavior}

\subsection{Modeling Choices}

The impact of the estate tax on potential donors' behavior depends critically on the nature and motivation behind the bequest motive. This poses an immediate challenge, because there are several different bequest motives considered in the literature. Bequests may be accidental, as a consequence of uncertain lifespan and an imperfect market for life annuities (Davies 1981, Hurd 1989). They may reflect altruism, in the sense that the expected well-being of a child affects the utility of a parent (Barro 1974). ${ }^{1}$ A parent may enjoy giving (Yaari 1965, Andreoni 1990), or he may enjoy being wealthy (Carroll 2000), preventing him from running down resources at the end of life. Bequests may also reflect some strategic interactions, e.g., with parents attempting to manipulate their children's behavior by holding out the chance of an inheritance (Bernheim, Shleifer and Summers 1985). They may also be a form of contract between subsequent generations (Kotlikoff and Spivak 1981). In what follows, we focus on a model with altruism and without strategic interactions between the parents and children, in order to highlight how taxes affect the key incentives of the donor.

\subsection{A Model with No Uncertainty}

In order to later highlight the role of uncertainty, we begin with a simple model with none at all. Consider an individual who values leisure and consumption during his life, and who also values the well-being of his heir. ${ }^{2}$ We can represent the individual's decision problem as follows

$$
\begin{aligned}
& \max _{C, L, G, A} u(C, L, G, v(y, I)) \\
& W=w L-T(w L)-C, \\
& I=W-G-E(W-G-A)-D(W, A) .
\end{aligned}
$$

\footnotetext{
${ }^{1}$ There is also literature on two-sided altruism; for a survey see Laitner (1997, section 3.1).

${ }^{2}$ For present purposes, we model an unmarried person with a single heir.
} 
Here $C$ and $L$ represent lifetime consumption and labor supply, respectively, $w$ is the wage rate, $T(\cdot)$ is the income tax function, and $W$ is the total bequeathable estate. $G$ represents charitable bequests (which are deducted from the estate tax base). The individual cares about the heir's utility, $v$, which depends on his own endowment $y$ and on $I$, the after-tax inheritance received by the heir; $E(\cdot)$ is the estate tax function. Taxes may be avoided at the cost of $D(W, A)$, where $A$ represents the amount of taxable income reduction. This specification allows, as in Slemrod (forthcoming), for the marginal cost of avoidance to be lower for larger estates, reflecting scale economies in avoidance, so that $D_{W}<0$ and $D_{A}>0$. Combining the first-order conditions leads to the following characterization of the optimal plan:

$$
\begin{aligned}
C: & \frac{u_{C}}{u_{v} v_{I}} & =1-E^{\prime}(W-G-A)-D_{W}(W, A), \\
L: & -\frac{u_{L}}{u_{v} v_{I}} & =w\left(1-E^{\prime}(W-G-A)-D_{W}(W, A)\right)\left(1-T^{\prime}(w L)\right), \\
G: & \frac{u_{G}}{u_{v} v_{I}} & =1-E^{\prime}(W-G-A), \\
A: & D_{A}(A) & =E^{\prime}(W-G-A) .
\end{aligned}
$$

The first-order conditions for this problem reveal that the marginal estate tax rate increases the cost of leaving an inheritance relative to consumption, leisure and charitable bequests. As with any tax, there will also be an income effect that, as long as all the goods are normal, will reduce $C$ and $I$, and increase $L$ (because leisure, not its complement labor, is the normal good). Of more interest (because it is unique to an estate tax) is the substitution effect, which will certainly reduce $I$ and will increase $C$ when it is not complementary to $I$ (or, more precisely, complementary to the utility of children), and reduce $L$ when leisure is not complementary to $I$. Absent complementarity, the substitution effect implies that end-of-life wealth will be lower with an estate tax, both because labor supply will be lower than otherwise and consumption will be higher than otherwise. In general, it is not possible to sign the uncompensated response. Finally, estate taxes are avoided up to the point where the marginal tax saving is equal to the marginal cost. To the extent that greater wealth facilitates avoidance $\left(D_{W}<0\right)$, this mitigates the disincentive effect of the estate tax on both saving and labor supply. Thus, whether avoidance opportunities soften the impact of the estate estate tax on "real" behavior depends on the technology of avoidance. This continues to be true in the models that follow, although for the sake of simplicity we ignore avoidance from 
this point on.

This model generalizes in a straightforward way to deal with multiple periods of life. For tractability, we consider a special case in which the utility of $N$ different periods is additively separable, so that

$$
u\left(C_{1}, L_{1}, \ldots, C_{N}, L_{N}, G, v(y, I)\right)=\sum_{i=1}^{N} \rho^{i} u\left(C_{i}, L_{i}\right)+\rho^{N+1} h(v(y, I), G),
$$

where $\rho$ is the per-period rate of utility discounting and $h$ is the utility derived from bequests to heirs and charities. ${ }^{3}$ The optimum is characterized by a series of relationships. ${ }^{4}$ First, there is an instantaneous optimality condition that relates consumption and leisure at each period of time,

$$
\frac{u_{C}\left(C_{i}, L_{i}\right)}{u_{L}\left(C_{i}, L_{i}\right)}=w\left(1-T^{\prime}\left(w L_{i}\right)\right)
$$

which states that the marginal rate of substitution between leisure and consumption should be equal to the wage rate net of the marginal income tax rate. Second, there are Euler equations that describe the evolution of consumption and leisure over time,

$$
\begin{array}{ll}
\frac{u_{C}\left(C_{i}, L_{i}\right)}{u_{C}\left(C_{i+1}, L_{i+1}\right)}=\rho(1+r), & i=1 \ldots N-1, \\
\frac{u_{L}\left(C_{i}, L_{i}\right)}{u_{L}\left(C_{i+1}, L_{i+1}\right)}=\rho(1+r) \frac{1-T^{\prime}\left(w L_{i}\right)}{1-T^{\prime}\left(w L_{i+1}\right)}, & i=1 \ldots N-1 .
\end{array}
$$

Equation 10 states that the marginal rates of substitution between consumption in adjoining periods should depend on the pure discount rate and the rate of interest (pre-tax, because we have not introduced capital taxes into the model). Equation 11 is the equivalent for labor supply, which must be adjusted across time for any changes in the marginal income tax rate. Finally, there are terminal conditions that relate consumption in the last period of life to the inheritance and charitable bequest,

$$
\begin{aligned}
\frac{u_{C}\left(C_{N}, L_{N}\right)}{h_{v} v_{I}(y, I)} & =\rho(1+r)\left(1-E^{\prime}\left(W_{N}-G\right)\right) \\
\frac{h_{G}(v(y, I), G)}{h_{v} v_{I}(y, I)} & =1-E^{\prime}\left(W_{N}-G\right), \\
-\frac{u_{L}\left(C_{N}, L_{N}\right)}{h_{v} v_{I}(y, I)} & =\rho(1+r) w\left(1-T^{\prime}\left(w L_{N}\right)\right)\left(1-E^{\prime}\left(W_{N}-G\right)\right)
\end{aligned}
$$

\footnotetext{
${ }^{3}$ Note that, because there is no uncertainty, there will never be a need for the individual to diverge from the consumption, work and bequest plan set out at the beginning of life.

${ }^{4}$ In deriving these conditions, we assume that there are no borrowing constraints and that terminal wealth is constrained to be non-negative.
} 
Without a bequest motive, the terminal condition would guarantee that the individual just exhausts his resources at the end of life. In the presence of a bequest motive, the estate is set so that the individual is just indifferent between consuming or working and leaving an inheritance. (This is conceptually identical to the analysis of the one-period model.) Holding wealth at the beginning of the last period constant, the estate tax induces an unambiguous substitution response toward more consumption and leisure. ${ }^{5}$ Due to the presence of a counteracting income response, it is not possible to sign the total effect. The Euler equations, which characterize the optimal paths of consumption and leisure, require that consumption (and leisure) in each period move in the same direction. In other words, a change in the estate tax shifts the lifetime consumption/labor profile without affecting its shape. However, both upward and downward shifts are consistent with the theory, depending on whether the income or substitution response to the estate tax of lifetime consumption and leisure dominates.

\subsection{A Model with Uncertain Lifetime}

In spite of Benjamin Franklin's injunction that the only certain things in life are death and taxes, uncertainty plays an important role in understanding the impact of estate taxes on donors' behavior. There is uncertainty about future income realizations of potential donors. This is the consideration that originally gave rise to the literature on the precautionary motive for saving. ${ }^{6}$ There may be uncertainty about future medical expenses and long-term care (see, Hubbard, Skinner and Zeldes 1994). There may be uncertainty about the endowment and therefore the well-being of the future generations, considered by Strawczynski (1994). Finally, there may also be uncertainty about the future rules that govern the taxation of wealth transfers. For example, individuals might want to avoid inter vivos gifts if they think that estate taxes may be reduced in the future.

We focus on the uncertainty about the lifespan of the donor, which affects decisions of the donor through a precautionary motive - the desire to avoid "outliving" one's resources. It is this

\footnotetext{
${ }^{5}$ Because of the assumed additively separable form of utility function, an increase in the price of inheritance induces a substitution response toward the composite good consisting of $C$ and $L$. It does not affect the relative prices of consumption and leisure so that when both these goods are normal, as we assume, they both increase.

${ }^{6}$ Note that if the uncertainty regarding income or wealth is resolved after most labor supply, human capital, and saving decisions are made, then taxation of estates may be very efficient, because it is a tax on luck.
} 
aspect that, in the presence of an imperfect market for annuities, produces accidental bequests. ${ }^{7}$ As is conventional in this literature, we assume that consumers are not allowed to freely purchase life annuities, but that some are exogenously available via Social Security benefits. ${ }^{8}$

As in the previous model, we consider an individual who maximizes an intertemporal utility function that depends on consumption, leisure and bequests left at death. ${ }^{9}$ In the presence of uncertainty, it is assumed that the individual is an expected utility maximizer, and so seeks to maximize

$$
\sum_{i=1}^{N+1} \rho^{i}\left(a_{i} u\left(C_{i}, L_{i}\right)+m_{i} v\left(y, I_{i}\right)\right)
$$

where as before $C_{i}$ and $L_{i}$ are consumption and labor in period $i, I_{i}$ is the (after-tax) inheritance left in case of death in period $i, u(\cdot)$ and $v(\cdot)^{10}$ are the instantaneous utilities from consumption and inheritances respectively, $N$ is the maximum possible age, and $\rho$ is the rate of time preference. We introduce some new notation, so that $a_{i}$ is the survival rate and $m_{i}$ is the mortality rate. The mortality rate $m_{i}$ is the probability of dying at the beginning of period $i$, and $a_{i}$ is the probability of being alive at the end of period $i$. The individual lives in the first period, so it is natural to assume that $a_{1}=1$ and $m_{1}=0$; she may live at most $N$ periods so that $a_{N+1}=0$. Mortality and survival rates are linked by the relation $m_{i}=a_{i-1}-a_{i}$ or, equivalently, $a_{i}=a_{i-1}-m_{i}$.

Optimization is, as in the certainty case, subject to the budget constraints,

$$
\begin{aligned}
W_{i+1} & =(1+r)\left(W_{i}+w L_{i}-T\left(w L_{i}\right)-C_{i}\right), \\
I_{i} & =W_{i}-E\left(W_{i}\right) .
\end{aligned}
$$

\footnotetext{
${ }^{7}$ There are a number of papers that are concerned with consumer behavior in this context (see, e.g., Yaari 1965, Richard 1975, Davies 1981, Abel 1985, Hurd 1989, Bernheim 1991). Some of these papers (Davies 1981, Abel 1985) consider accidental bequests in isolation; others (Hurd 1989, Bernheim 1991) allow also for other types of bequest motives.

${ }^{8}$ Barro and Friedman (1977) noted that when insurance markets are perfect and actuarially fair, mortality and survival rates do not affect consumption and bequest decisions. An intuition for this result is simple. A decrease in the mortality rate increases the value of future consumption to an individual. At the same time, it increases its price because annuities become more expensive when people are expected to live longer. With actuarially fair insurance markets, these two effects cancel out.

${ }^{9}$ For simplicity, we do not model charitable bequests.

${ }^{10} \mathrm{With}$ an appropriate interpretation of the function $v(\cdot)$, it may also be considered as a reduced form of the altruistic model (Abel and Warshawsky 1988).
} 
The Euler equation in this model can be written as follows: ${ }^{11}$

$$
\begin{aligned}
u_{C}\left(C_{i}, L_{i}\right) & =\rho(1+r)\left(\frac{a_{i+1}}{a_{i}}\left(u_{C}\left(C_{i+1}, L_{i+1}\right)+\frac{m_{i+1}}{a_{i}} v_{I}\left(y, I_{i+1}\right)\left(1-E^{\prime}\left(W_{i+1}\right)\right)\right)\right. \\
\text { or } \quad u_{L}\left(C_{i}, L_{i}\right) & =\rho(1+r) \frac{1-T^{\prime}\left(w L_{i}\right)}{1-T^{\prime}\left(w L_{i+1}\right)}\left(\frac{a_{i+1}}{a_{i}} u_{L}\left(C_{i+1}, L_{i+1}\right)\right. \\
& \left.+\frac{m_{i+1}}{a_{i}} w\left(1-T^{\prime}\left(w L_{i+1}\right)\right)\left(1-E^{\prime}\left(W_{i+1}\right)\right) v_{I}\left(y, I_{i+1}\right)\right) .
\end{aligned}
$$

Compare equation (18) to the certainty version of equation (10). The marginal benefit of consumption is unchanged, but the marginal benefit of postponed consumption now must account for the fact that it allows for either increased own consumption or an increased bequest, with the two weighted by the probability of surviving until the next period. The estate tax reduces the payoff to saving because it reduces the amount of inheritance that a unit of postponed consumption creates. This effect is present in every period, but only next period's marginal tax appears directly in any single Euler equation, and its effect is proportional to the mortality rate. It would be a mistake, however, to conclude that this is the full effect. Consumption after period $t+1$ is also affected by taxes, and from the Euler equation we may conclude that (expected) consumption in period $t+1$ is a sufficient statistic for the influence of estate taxes after that period.

The estate tax also affects labor supply, as demonstrated by the presence of the tax term in equation 19. The wage rate relevant for the labor supply/inheritance margin is $w\left(1-T^{\prime}\right)\left(1-E^{\prime}\right)$, i.e., the estate tax reduces the payoff to working. As in the certainty case, labor supply and consumption at a point in time are instantaneously related by equation 9 , so that the relevant wage rate on this margin is still $w\left(1-T^{\prime}\right)$.

As stressed by Hurd (1989), in the last possible period of life there are two possibilities: either an individual is willing to leave a bequest, in which case terminal conditions (12-14) apply, or not, in which case there are no such conditions and final consumption is pinned down based on the budget constraint and the Euler equation. ${ }^{12}$ In general, the more wealthy an individual is, the more likely it is that a bequest will be left. Leaving a bequest with certainty may be guaranteed by imposing the condition that $\lim _{I \rightarrow 0} v_{I}(y, I)=+\infty$, which implies that one wishes at all costs to

\footnotetext{
${ }^{11}$ It is assumed that the wealth constraints are not binding. If they were, this first-order condition would become an inequality, with equality whenever the constraint is not binding.

${ }^{12}$ Note that even though one may not wish to leave bequests upon reaching a certain age, the marginal utility from bequests is still present in the Euler equation because accidental bequests also yield utility.
} 
avoid the possibility of leaving no bequests at all. ${ }^{13}$

The Euler equation may be iterated forward to yield the following formula,

$$
u_{C}\left(C_{1}, L_{1}\right)=a_{N} \rho^{N-1}(1+r)^{N-1} u_{C}\left(C_{N}, L_{N}\right)+\sum_{i=2}^{N} m_{i} \rho^{i-1}(1+r)^{i-1} v_{I}\left(y, I_{i}\right)\left(1-E^{\prime}\left(W_{i}\right)\right)
$$

When the individual plans a bequest, this equation further simplifies to

$$
u_{C}\left(C_{t}, L_{t}\right)=\sum_{i=t+1}^{N+1} m_{i} \rho^{i-1}(1+r)^{i-1} v_{I}\left(y, I_{i}\right)\left(1-E^{\prime}\left(W_{i}\right)\right) .
$$

Equation (21) implies that consumption in any period depends on the value of $m_{i}\left(1-E^{\prime}\left(W_{i}\right)\right)$ for all subsequent periods.

\subsection{A Simulation Exercise}

To get more insights into the nature of behavioral response and to empirical challenges we will confront in Section 4 and 5, we can simulate individual behavior using a stylized utility function. To do so, we assume that an individual maximizes lifetime utility given by

$$
\sum_{i=25}^{115} \rho^{-i}\left(a_{i} \frac{C^{1-\gamma}}{1-\gamma}+m_{i} \alpha \frac{B_{i}^{1-\delta}}{1-\delta}\right)
$$

where $C_{i}$ is consumption in period $i, B_{i}$ is the bequest in case of death at the end of period $i, \rho$ is the discount factor, $a_{i}$ is the probability of survival until period $i$ and $m_{i}$ is the probability of death in period $i$. Initial wealth $W_{25}$ is assumed to be zero. The simulated lifetime begins when at age 25 , and the maximum possible age is 115 . Mortality and survival rates are taken from the population actuarial life tables for males. Neither annuities nor life insurance are available, and the optimization is subject to the following two constraints,

$$
\begin{aligned}
W_{i+1} & =(1+r)\left(W_{i}+Y_{i}-C_{i}\right), & & i=0 \ldots N, \\
B_{i} & =W_{i}-T\left(W_{i}\right), & & i=1 \ldots N+1,
\end{aligned}
$$

where $Y_{i}$ is (exogenously given) income in period $i$, and $T_{i}(\cdot)$ is the estate tax function.

It is assumed that $\gamma=2, \rho=.97, r=.03, \alpha=.1$ and $\delta=.5 \gamma$. This last parameter implies that, over the lifetime, bequests increase approximately twice as fast as consumption. The individual is

\footnotetext{
${ }^{13}$ If this assumption is made, the wealth constraint would never be binding because, if it was, the marginal utility from bequests would be infinite, which may not be optimal.
} 
assumed to have a constant stream of income of $\$ 200,000$ a year until the age of 65 , and no income thereafter.

Figures 1 and 2 consider the case in which the representative individual starts his economic life facing the current U.S. tax system, and is convinced that it will be in effect for the rest of his life. After 20 years of living in this regime, however, the tax system changes unexpectedly, and the estate tax is abolished completely. What effect does this have on the lifetime pattern of consumption and bequests?

Figure 1 shows the effect on the path of wealth accumulation, for two individuals who differ only in level of endowment. Eliminating the tax increases wealth, and the effect gets larger with age. Figure 2 shows the effect on the path of consumption. Consumption falls immediately, but if one lives long enough, consumption may ultimately increase above what it would otherwise be. An intuition for this result is as follows: at the maximum possible age, an individual is planning to hold more wealth than he otherwise would. As a result, the marginal utility from leaving a bequest is lower, and thus there is an incentive to consume more (than one otherwise would) close to that date. It is important to note that the magnitude of the response to the tax change is sensitive to the parameterization of the model.

There are several insights to be taken from this simple simulation. First, the effect of the estate tax on wealth depends on the age of an individual. Second, the full effect is not visible until many years after the tax reform. Finally, compare points A and B in figure 1. Although point $\mathrm{A}$ is an observation from a zero estate tax regime and point $\mathrm{B}$ is an observation from a high estate tax regime, the estate at B exceeds the wealth at A even though estate taxes reduce wealth accumulation in this simulation model. The behavioral response to taxation will, though, be revealed in an empirical anlaysis only to the extent that the level of endowment can be held constant in some way. Because no information about lifetime income is available in the analysis below, other assumptions are required.

More generally, the response of wealth accumulation to a change in the estate tax will depend on the responsiveness of labor supply to a change in its net reward, and on the responsiveness of lifetime consumption versus bequests to its relative price. This cannot be revealed by theoretical analysis, but only by empirical analysis. Moreover, the income effect may partly or fully offset 
the relative price effects, so the sign of the net effect is not definite. Finally, as Gale and Perozek (this volume) emphasize, the qualitative effect of the estate tax on private saving depends on why donors give bequests and how saving by the donee is affected. They argue that in plausible models the estate tax may increase the combined saving of the donor and donee. The same point applies to the avoidance response: theoretical reasoning can determine neither the magnitude of the response nor the sensitivity of the response to the tax structure.

Both because the key parameters of the altruism model are unknown and because the "right" model of bequests, be it altruism or some other, is unknown, the response of potential donors to the estate tax is ultimately an empirical question. Before attempting to advance our understanding of this question in Section 4, we next briefly review some relevant literature.

\section{Previous Empirical Literature}

\subsection{The Effect of the Estate Tax on Wealth Accumulation}

In his survey of the U.S. federal estate and gift tax, Joulfaian notes that estate taxes may reduce the work effort and savings of parents motivated to leave large bequests to their children, but states that "there is no empirical evidence" on either type of behavioral response (Joulfaian 1998b, p. 25). Because the estate tax is a particular kind of tax on return to working and saving, the large empirical literature on how the income tax affects these two decisions is, however, certainly relevant. If taxes affect neither, it is unlikely that the estate tax could affect wealth accumulation. We cannot adequately survey the enormous literature on these topics here, although we refer the reader to the able surveys by Blundell and MaCurdy (1999) on labor supply and by Bernheim (1997) on saving. Although the consensus of these literatures - that neither is very responsive to taxes - suggests that the impact of the estate tax on wealth accumulation is not large, there is almost no direct analysis of this question.

In an earlier era, Fiekowsky (1966) argued that there was no indication that estate accumulators were discouraged by the sharply increased death tax rates introduced in the 1930s and early 1940s. He asserts that if there had been such discouragement, one would have (but did not) observe three phenomena: (i) the distribution of estate taxpayer estates would have become more equal, as the 
larger estates failed to grow and the smaller estates (truly held for consumption) increased slightly, (ii) the proportion of widows among estate taxpayers would have risen, as active accumulators moved to thwart the IRS, since widows would report estates inherited from the prior generation of unthwarted accumulators, and (iii) a marked effort to minimize transfer tax liabilities by making gifts and creating generation-skipping transfers would have been manifested.

\subsection{The Effect of the Estate Tax on Avoidance and Evasion}

Tait (1967) estimates the extent of avoidance of the estate tax in Great Britain by comparing the distribution of taxable estates in a low-tax year (1912) to the distribution in a high-tax year (1960). He first applies 1960 estate tax rates to the 1912 distribution and expresses the tax yield as a fraction of total wealth held in 1912. He then compares this figure to the actual 1960 revenue yield as a fraction of total wealth held in 1960, and finds that the 1912 figures exceed these of 1960 by between 1.3 and 1.5 times. This leads Tait to conclude that avoidance amounts to between 34 and 50 percent of the potential 1960 base. Note, though, that the total wealth estimates in the denominator are themselves derived from estate tax returns and are thus skewed by any avoidance. Furthermore, the large time span between the two years suggests that much other than the tax structure changed and may confound the methodology.

Wolff (1996) estimates U.S. estate tax avoidance by comparing the actual tax base to an estimate of what the base "should be" based on the comprehensive wealth survey in the 1992 Survey of Consumer Finances (SCF) conducted by the Federal Reserve Board. He first applies mortality rates by age, gender, and race to the population represented by the $1992 \mathrm{SCF}$ file. He calculates the total net worth of decedents to be $\$ 241.5$ billion in 1993 , which compares to $\$ 99.4$ reported on estate tax returns. He then adjusts the net worth of each "probabilistic" decedent by the average marital and charitable giving deduction in the estate class and applies the federal estate tax schedule. On this basis, Wolff's simulation indicate that estate tax collections should have been $\$ 44.5$ billion in 1993 , compared to $\$ 10.3$ billion in actual collections. He concludes that more effective enforcement of the estate tax might have yielded another $\$ 30$ billion in revenue in 1993 .

However, Poterba (2000) performs a similar exercise and concludes that the estimated tax liability corresponds quite closely to actual estate tax liability. The stark difference in conclusion is 
partly due to the fact that Poterba uses a mortality table that describes the mortality experience of individuals who purchase single-premium annuities from life insurance companies, who are generally from the upper tail of the wealth distribution and are arguably representative of the estate tax paying population. In contrast, Wolff uses the population mortality table, and may therefore be overestimating the fraction of wealthy people who are subject to estate tax in a given year. ${ }^{14}$ Eller, Erard and Ho (this volume) revisit the Wolff-Poterba methodology, and find that the conclusions are highly sensitive to assumptions about differential mortality rates of married and unmarried individuals, and the distribution of charitable contributions across estates in a given gross estate category. Because of this sensitivity, they caution against taking too seriously estimates of avoidance or evasion based on this type of approach. Moreover, these studies are attempts to estimate the size of avoidance (and evasion), but none addresses the sensitivity of this magnitude to changes in the estate tax structure.

Not only avoidance, but also (illegal) evasion, may be sensitive to the tax structure. However, little is known about this effect. Certainly, the audit coverage of estate tax returns is relatively high. Eller and Johnson (forthcoming) report that in 1992, 11,338 estate tax returns were audited, which comprises $19.2 \%$ of the total number of filed returns. The audit rate increases with the size of the gross estates, with an $11.1 \%$ audit rate of estate under $\$ 1$ million, $26.5 \%$ of estates between $\$ 1$ million and $\$ 5$ million, and $48.5 \%$ of estates over $\$ 5$ million. Because of the concentration of audits on the largest estates, although $19.2 \%$ were audited, returns with $63.2 \%$ of the reported tax liability were subject to audit.

Eller and Johnson do not estimate an estate tax "gap," but report that as a result of audit, net estate tax liability increased by $\$ 559.8$ million, which is $8.7 \%$ of the total reported tax liability of the returns that were audited. Of audited cases, 60.0 percent were closed with additional estate tax owed, 19.0 percent were closed with no change in assessment, and 21.0 percent were closed with a reduction in the original net estate tax liability. Erard (1999) estimates the tax gap to be $13 \%$ of potential revenues. Neither Eller and Johnson nor anyone else has tried to estimate the responsiveness of estate tax evasion to changes in either the tax structure nor to the level of

\footnotetext{
${ }^{14}$ Another difference is that Wolff uses a re-weighted version of SCF dataset that generates a larger wealth holdings than the public-use weights used by Poterba.
} 
enforcement resources and their application.

The closest antecedent to what we attempt in this paper is Chapman, Hariharan and Southwick (1996), who regress the logarithm of real revenues from the estate tax in 1958 through 1994 against the logarithm of real GNP and the logarithm of the marginal estate tax on an estate of real value equal to $\$ 1,400,000$ in 1989 . The response of revenues should reflect both avoidance and, with a lag, wealth accumulation. They estimate a significant negative coefficient on the tax rate variable, with an elasticity of revenues with respect to the marginal tax rate of about -2 . They note, however, that three other definitions of the marginal tax rate "did not give as strong an effect," made no attempt to control for other influences on revenues other than the level of GNP, and included no time trend, which might be especially important given that the measure of marginal tax rate increases monotonically over this period. In the empirical analysis that follows, we examine a longer time period over which the estate tax structure rises and falls, and allow for non-tax influences on reported estates as well as a time trend. Furthermore, we examine reported estates rather than revenues in order to separate out the behavioral effects of changes in the tax structure from the direct revenue impact of such changes.

In summary, although the existing literature has addressed aspects of the behavioral response to the estate tax, there is not much solid empirical research to inform policy. To be sure, as we elaborate on below, there are substantial methodological challenges to overcome in obtaining such evidence.

\section{Analysis of Aggregate Time-Series Evidence}

\subsection{Motivation and Methodology}

Although the technology of life and death means that panel data is (and will in the foreseeable future be) unavailable, it is still possible to investigate the impact on behavior of the changes over time in the rates and rules regarding the estate tax. Since its introduction in the Revenue Act of 1916, there have been many changes in the rate structure, base, deductions, treatment of gifts, creditability of state estate and inheritance taxes, and other aspects of the tax. In what follows we make use of some aspects of that variation to examine the impact of the estate tax on aggregate 
wealth accumulation and avoidance.

The ultimate goal of the empirical analysis is to provide evidence of how the estate tax structure has affected wealth accumulation and avoidance. Of course, the counterfactual - what estates would have been under a different tax structure - is not known. We are forced to rely on inference based on the relationship between what is observed - reported estates of the very wealthy - and some other variables. For example, one might examine the ratio of estates subject to the estate tax to the total of all estates, under the assumption that, were it not for the estate tax, this ratio would stay fairly constant. Alas, the amount of total estates is not known, because we do not observe the estates of the vast majority of the population that is not subject to estate taxation.

There is, however, information about the aggregate net worth of the whole population. If the relationship between aggregate net worth and total estates of decedents remains fairly constant over time, one can use net worth as a benchmark against which to examine the response of taxable estates to changes in the tax structure. We pursue this strategy in what follows. Studying this relationship qualitatively is in the spirit of the work of Feenberg and Poterba (1993), who in an influential article calculated the share of total taxable income received by the top $0.5 \%$ of income earners, and discussed the extent to which it could be explained by the variation in the income tax rates on this group relative to the population as a whole.

The dependent variable we seek to explain is the ratio (to aggregate net worth) of total reported net estates (gross estate minus debts) of a fixed percentile of the largest estates. To avoid spurious results due to changes over time in mortality experience (which would affect the total estates of a given fraction of the wealthiest taxpayers in a mechanical way), we normalize this variable by the mortality rate. The variable we construct is defined as

$$
\text { estratio }{ }_{t} \equiv \frac{E_{t}}{0.005 m_{t} W_{t}}
$$

where $E_{t}$ is the value in year $t$ of estates of the richest $0.5 \%$ of decedents, $W_{t}$ is aggregate net worth, and $m_{t}$ is the mortality rate. Noting that $0.005 m_{t}$ is just the ratio of the number of deaths in the top $0.5 \%$ to the total population, estratio $o_{t}$ may alternatively be expressed as $\frac{\bar{E}_{t}}{\bar{W}_{t}}$, where $\bar{E}_{t}$ is the average estate of the wealthy decedent group and $\bar{W}$ is the average wealth among the whole economy.

It is important to be clear that in what follows we are examining the determinants of reported 
net worth on estates rather than reported taxable estates. Analyzing the latter raises a difficult empirical problem because the definition of taxable estate changed several times over the period we study, and we do not have sufficient data to construct a series according to a consistent definition. Not adjusting the data causes problems of interpretation, discussed in the context of taxable income in Slemrod (1998). Over this period, the definition of gross estate and net worth was more stable, although there were certainly changes, regarding for example inclusion of the property owned jointly by a married couple, which we attempt to account for in our analysis. Thus, our analysis focuses on the association between the tax structure and gross estate or net worth, rather than taxable estate. This compromise due to data constraints almost certainly leads to an understatement of the true elasticity of the tax base. The data sources and estimation procedure are described in detail in the appendix.

In order to investigate whether taxes had a significant impact on reported estates, we need a measure of the tax rate that is not in any way endogenously determined by the distribution of actual estates. We explore three such measures. The first is the statutory marginal tax rate that applies to the largest estates (TTOP). Clearly, no decisions of the taxpayers affect this value instantaneously. Although one could argue that over time the concentration of estates may, through the political process, influence the tax structure, we ignore this possibility. The other two measures of the tax rate we investigate are the marginal tax rate at 100 times (T100) and 40 times (T40) the level of aggregate wealth per capita. The tax rate at 40 times average wealth is of interest because it corresponds to a sequence of wealth that was subject to the estate tax throughout the whole period, and yet only very recently did the highest tax bracket apply to it.

\subsection{Results}

Figures 3 through 5 plot estratio against each of the three tax rate indicators. The tax rate measures are shown for each year, although estratio is only available (here and in the regression analysis that follows) for selected years. For both T100 and T40, there is an apparent and striking negative relationship between the tax variable and the estate/wealth ratio-the two series are practically mirror images of each other. Indeed, the simple correlations are -0.87 and -0.86 for T100 and T40, respectively. The sharp increase in the estate tax rates beginning in the early 
1930's coincides with a sharp decrease in reported estates, and the halt and, in the case of T100, decline of the rates beginning in the early 1980's coincides with the timing of a turnaround in the estate ratio. For TTOP, the negative relationship is not quite as striking, but there is nevertheless a correlation of -0.49 between the two series. ${ }^{15}$

A few features of the tax rate series are worth pointing out. Increases in T100 and T40 between 1942 and 1976 are solely due to "bracket creep" - the nominal tax brackets remained unchanged while the average wealth was increasing (both in real terms and due to inflation). In the 1980's, the T100 series was equal to TTOP, ${ }^{16}$ and both series stabilized with the aggregate estates. The T40 series, however, paints a different picture. Although the highest tax rates decreased in the early 1980s, this is not true for the tax rates that applied at this more moderate level of wealth. Instead, the marginal tax rate continued to increase due to both real and nominal changes in aggregate wealth. Legislated increases in the exemption level were just too small to matter.

The strong negative correlation between estratio and the tax rate measures does not establish that the changes in the estate tax caused the changes in reported estates. For one thing, there may have been other factors influencing this variable that are coincidentally related to the evolution of the estate tax. For instance, the correlation of estratio with the real S\&P 500 index is -0.59 . We can, of course, go beyond ocular econometrics and investigate formally the relationship between the estate/wealth ratio and the estate tax structure in a regression framework, in a way similar to Slemrod's (1996) investigation of the determinants of the Feenberg-Poterba high-income share of total income. The multiple regression framework allows us to statistically hold constant non-tax factors that changed over time that might be expected to influence this variable.

We investigate two non-tax and two tax but non-estate-tax explanatory variables. The first non-tax variable is the contemporaneous inflation-adjusted level of the S\&P 500 stock market index. This is included because changes in asset values will affect the value of estates in a way that cannot be offset by changed behavior. On the reasonable assumption that the portfolio of

\footnotetext{
${ }^{15}$ Note that not correcting for mortality rate would make it even more striking, because the mortality was decreasing over time and thus without this correction the additional downward-sloping time pattern would be present in the estate series.

${ }^{16}$ The increase in T100 in 1996 is due to a phase-out of the exemption and lower tax rates at smaller estates that increases the marginal tax rate on estates between $\$ 10$ and $\$ 21.4$ million to $60 \%$.
} 
high-wealth individuals is likely to be relatively more concentrated in stocks, we expect to find a positive relationship between the stock market index and estratio, a relationship that is unrelated to a behavioral response to taxation. We also include a ten-year lagged value of the inequality of income, measured as the share of income going to the richest $5 \%$ of the population (see the appendix for the source of this series). This variable is meant to proxy for the inequality of lifetime endowments which, other things equal, would later cause inequality in estates. Of course, income realizations depend not only on endowments, but also on factors such as labor supply and effort, which may have themselves been affected by the estate tax structure, and therefore the income inequality measure may be endogenous. This problem is somewhat alleviated by using the lagged value of the inequality measure.

To control for the possible effects of other tax variables, we also include as explanatory variables the indiviudal income tax and, separately, the corporation income tax rates that applied to the highest bracket of individual and corporation income, respectively. Both of these variables were lagged ten years to account for the fact that they were more likely to be important during the individual's working years.

The regression results are presented in Table 1. The dependent variable is the logarithm of estratio. In the basic specification, shown in the first three columns, the right-hand-side variables include a constant, the log of one of the three measures of the net-of-tax rate $(1-t)$, the inflationadjusted stock market index, the income inequality measure, and the two lagged tax rate terms.

The coefficients of the (net of) estate tax rate variables are in all cases positive and are in all but one case significant at the $1 \%$ level, suggesting that an increase in taxes is indeed associated with reduced reported estates relative to aggregate wealth. As expected, the stock market variable has a positive association with the estate variable, with an estimated coefficient between 0.23 and 0.31. The coefficient on lagged income inequality is also positive but not significantly different than zero.

Both the lagged individual and corporate income tax rates are significantly related to estratio, but not necessarily in an expected way. Higher income tax rates are associated with an increase of the ratio of reported estates to aggregate wealth, while higher corporation income tax rates are associated with a decrease. The former result is not consistent with the idea that high income 
tax rates depress both labor and saving, causing lower wealth accumulation. The pair of results is, though, consistent with the idea, explored in Gordon and Slemrod (2000), that high individual income tax rates cause income to be retained by corporations rather than being paid out to business principals. If, due perhaps to liquidity constraints, the shifting toward the corporate tax base reduces the propensity to consume, this could produce the pattern of associations with tax rates displayed in Table 1.

Given that the key series appear to be trending, it is not surprising that the fit of these regressions is very good. The reported Durbin-Watson statistics are, however, low, reflecting significant positive autocorrelation. The presence of missing data makes it impossible to address the problem of autocorrelation using standard approaches, as it would require deleting all of the isolated observations. However, the observed autocorrelation may be simply caused by misspecification of the model, and when we control below for other relevant factors the problem is mitigated.

Our measure of the magnitude of the top estates is normalized by the aggregate wealth and the death rate. Implicitly, this procedure amounts to restricting the coefficients on wealth and the death rate in a regression explaining total estates to be equal to one. However, either of these variables may have an independent effect on the largest estates. For example, it may be that the inequality of wealth is systematically related to the level of development. Furthermore, during the $20^{\text {th }}$ century, there were significant trends in the mortality rate and the expected length of life. These factors may affect the size distribution of estates by affecting the age structure of decedents and their lifetime behavior. The death rate may be used as a proxy for these considerations.

The next three columns of Table 1 augment the original specification by adding as explanatory variables the level of aggregate wealth, the death rate, and a time trend. The coefficients on the tax rate variables remain significant in two out of three cases, although they are somewhat smaller. The coefficient on the S\&P 500 index increases, while the coefficient on lagged income inequality becomes negative and significant in two out of three cases. We find that there is a negative time trend. Both aggregate wealth and the death rate enter significantly and negatively. The coefficients on the aggregate wealth are between -0.62 and -0.81 , suggesting that $1 \%$ increase in aggregate wealth is associated with only between a $0.18 \%$ and $0.39 \%$ increase in the wealth of the rich. It should be pointed out, however, that the relative wealth of the rich is also affected by changes in 
the stock market, which are undoubtedly causally related to aggregate wealth. This introduces a qualification to the interpretation of the estimated coefficient on wealth. ${ }^{17}$

The estimated coefficients on the measures of the net-of-tax rate are between 0.083 and 0.335. In the logarithmic specification, these coefficients can be interpreted as elasticities. However, one has to be careful in interpreting these coefficients as elasticities with respect to the tax rate, because one cannot adequately characterize the whole tax system by means of a single rate, and even if it were possible it is not clear how exactly our measures are related to it. Still, these estimates are suggestive in assigning to the estate tax a moderate but statistically significant role in the determination of aggregate reported estates of wealthy Americans. ${ }^{18}$

\subsection{Caveats to Interpreting the Aggregate Analysis}

Although the aggregate results are consistent with the notion that the estate tax causes lower reported estates, a number of caveats to this conclusion are in order. First of all, it may be that the rates themselves responded to aspects of economic performance. Certainly the largest increase in rates occurred at the beginning of the Great Depression. This may have reflected the view that in a period of widespread destitution a highly progressive tax on wealth is more defensible. Notably, the drop in the estate/wealth ratio occurred before the estate tax increase began.

We also acknowlege that our summary measures of the marginal estate tax rate do not account for many relevant features of the estate and gift system. For example, the treatment of gifts changed dramatically over the period, leading to the present "unified" treatment of estates and gifts beginning in 1981. The treatment of state-level inheritance, estate, and gift taxes also changed dramatically, such that at first they were incremental taxes and by the end of the period they were largely creditable, and therefore not incremental. These and certain other aspects of the U.S. tax system are not captured in this analysis. Undoubtedly, this imprecision adds measurement error

\footnotetext{
${ }^{17}$ It is also worth noting that, because wealth is in the denominator of the dependent variable, errors in measuring it will introduce a negative bias to the estimated coefficients.

${ }^{18} \mathrm{We}$ also investigated a number of other modifications of this specification, such as including lagged values of the S\&P 500 index, adding dummies for years when the unlimited marital deduction was in effect, and for the World War II period. The qualitative results are robust to these changes. We also investigated adding a lagged value of the tax variable. Usually it was insignificant, and the coefficient on the contemporaneous value was not qualitatively affected.
} 
to the tax variables that will tend to bias the estimated tax coefficients toward zero. Moreover, if the mismeasurement is systematically related to the included independent variables, it could lead to bias of any direction in the estimated coefficients. We leave refinement of these summary tax measures to future research.

A more technical issue concerns what has been labeled "rank reversals." This refers to the possibility that in periods when taxes are high, the high estate group we are focusing on is no longer composed of the wealthiest individuals, but rather the relatively poor avoiders, or those who are unwilling to cut back on wealth accumulation. This phenomenon implies that the composition of this group changes systematically with tax changes. Note, though, that the direction of the bias is to find less response of reported estates to tax changes, because we would underestimate the true decrease in estates due to an increase in taxes.

Because the decision to accumulate or spend wealth is usually made in the context of a family, it is conceivable that people with differing marital status may react differently to the tax rates. For example, a couple may react differently to features of the estate tax that affect marital bequests (on the estate of the first spouse dying) than to taxes on estates of the second spouse. Such issues may not be adequately analyzed with aggregate data, if the cross-sectional composition of families has changed over the sample period. Furthermore, as mentioned above, a varying amount of spousal bequests, changing in part because of the variation in the relevant tax incentives, may influence the extent to which wealth accumulation appears twice in the estate tax return data.

Finally, any analysis of annual aggregate data relies on a small number of tax changes and observations, so that definitive conclusions cannot be drawn. We stress that the results are consistent with a behavioral response to estate tax rates, but do not decisively establish such a relationship.

\section{Analysis of Pooled Estate Tax Return Data}

\subsection{The Promise of Micro Analysis}

Examining data from estate tax returns that is aggregated by years may obscure the relationship between the tax system on the one hand, and wealth accumulation and tax avoidance behavior on the other. To take a simple example, in a year when the tax law changed it does not allow us to 
differentiate the estates reported in the two different tax regimes. ${ }^{19}$ More importantly, aggregate analysis precludes examining whether the impact of the tax system is moderated by individualspecific attributes, such as age at death or the presence of a surviving spouse.

In this section we examine the data from individual estate tax returns, with the goal of identifying the tax and non-tax determinants of taxable estates. At first blush, one might expect that the greatest advantage of analyzing individual tax return data lies in the ability to calculate tax rates on a return-by-return basis, rather than having to use summary statistics that characterize the tax system in place but that do not vary by individual. However, the econometric analysis of taxation using micro-level estate tax return data is plagued by the ubiquitous problem that, in a graduated tax system like that of the U.S., the marginal tax rate is a function (only) of the taxable estate. This raises the danger of detecting a positive correlation between the level of the estate and the marginal tax rate that is unrelated to any causal relationship between tax rates and behavior. This may obscure a causal negative relationship between the tax rate and reported estates. We return to this issue below.

As our foundation, we appeal to the model of Section 2.3 in which the only uncertainty is about longevity, and annuities are not available. In this case, wealth at death is a function of the present value of the endowment (including the ability to earn net-of-tax income and any inheritance received), the after-tax rate of return to saving, age at death, the individual's tastes regarding labor versus leisure, regarding bequests versus own consumption and present versus future consumption (the discount rate), and the estate tax structure. In what follows we first outline our empirical strategy for examining the impact of estate taxation on wealth accumulation and avoidance, and then discuss the observable proxies for the marginal tax rate and other factors that influence the estate.

Our data come from estate tax returns collected by the IRS from 1916 until 1996. The dataset, which was also the source of the aggregate analysis of Section 4, is described in detail in the appendix. It contains information on almost 770,000 decedents. The filing threshold and, consequently, the coverage of the estate tax varied over the years, so that the composition of population

\footnotetext{
${ }^{19}$ In the aggregate analysis we account for this problem by taking as a measure of the tax rate in a given year a weighted average of the relevant tax rates (with weights proportional to the time they were in effect).
} 
subject to the tax in different years changed. Given that time series variation is an important source of identification, the varying coverage could lead to spurious conclusions. For that reason, we construct a more homogenous sample by analyzing, as in the aggregate analysis, the estates of the richest $0.5 \%$ of U.S. decedents in each year. This procedure ensures that every observation for every year of death represented in the data corresponds to an estate well above the filing threshold. This limits the sample to slightly more than 310,000 decedents.

\subsection{Calculating the Individual-Specific Marginal Tax Rate}

\subsubsection{Calculating the Marginal Tax Rate}

The key explanatory variable is the marginal estate tax rate applicable to an individual. It is a component of the "price" of leaving a bequest relative to lifetime consumption and relative to leisure, as well as being the reward to reducing via avoidance the taxable estate by one dollar. The marginal tax rate is not present explicitly on the tax return. We construct it by applying the actual tax schedule in effect at the time of death of the indvidual to a measure of the taxable estate. Details of this procedure may be found in the appendix.

We also investigate two measures of the marginal tax rate that might be expected during the lifetime of an individual: the tax rate at age of 45 (RATE45) ${ }^{20}$ and the tax rate 10 years before death (RATE10). Both are evaluated at the actual taxable estate at death, denominated in dollars of the relevant year, but using the tax rate schedule in effect in these earlier years. Investigating these tax rate measures may also prove helpful in two other ways. First, if one believes that avoidance measures, as distinct from labor supply or consumption decisions, are decided late in life, then the response to the tax rates expected earlier in life may separately identify the wealth accumulation behavioral response. Second, these variables are much less susceptible to the possibility that they are, via a political reaction, endogenous to the economic situation.

\subsubsection{The Marginal Tax Rate for Married Couples}

In defining the marginal tax rate that affected wealth accumulation and avoidance decisions, an important issue is the treatment of spousal bequests. To see the issues involved, recall that the 1981

\footnotetext{
${ }^{20}$ For individuals who died before reaching age 45 , we assume that RATE45 is equal to RATE.
} 
Economic Recovery Tax Act provided for an unlimited deduction for bequests to surviving spouses. Under previous law (going back to 1948) the deduction for spousal bequests was limited to one-half of the adjusted gross estate. (From 1977 to 1981 the deduction was the greater of $\$ 250,000$ and one-half of the adjusted gross estate). Under these two regimes, what is the appropriate marginal tax rate on a given taxable estate for a decedent with a surviving spouse?

One possible approach to this question is to calculate the marginal tax rate for a constant spousal bequest. Comparing two returns with the same gross estate, this procedure assigns a marginal tax rate of zero to a return with a sufficiently large spousal bequest deduction, and assigns a positive tax rate to the one with no spousal bequest deduction. In the context of estimating the impact of the estate tax on charitable bequests, Joulfaian (1998a) argues that the unlimited marital deduction helps to alleviate the problem of separating the wealth effect and the marginal tax rate effect; because estates vary greatly in the amount of spousal deduction, Joulfain argues that this provides a source of variation in the effective tax rate for a given level of wealth. But this procedure provides identification only under the assumption that the behavior under study, in his case charitable contributions, does not independently depend on whether there is a surviving spouse.

For estimating the tax disincentive effect on wealth acumulation, calculating the marginal tax rate ignoring the eventual taxation of the surviving spouse's estate is almost certainly inappropriate. In a model where the couple cares only about the total net-of-tax bequest, even if there is no tax levied upon the first decedent because all the estate is left to the surviving spouse, the effective tax rate is that of the last dying spouse. Because we cannot link estate tax returns from the same family, we are unable to measure that precisely. However, the size of the spousal bequest reveals some information about this, because this bequest becomes the inheritance of the surviving spouse, whose eventual estate equals that inheritance, plus any assets held separately at the time of the first spouse's death, plus subsequent earnings, minus consumption.

Furthermore, note that the household that cares only about the total net-of-tax bequest should equate the expected marginal tax rate levied on the two estates, and will not do so only to the extent there are costs associated which it, such as, e.g, liquidity constraints that may be faced by small business owners. If such non-tax costs apply to the first spouse only, the relevant marginal 
cost of taxation is approximated by the rate faced by the second spouse, which is equal to the marginal tax rate of the first spouse plus the unobservable marginal cost.

This discussion suggests that the relevant marginal tax rate that would be expected to affect wealth accumulation decisions is not necessarily well measured by the observed marginal tax rate of one member of a married couple. Furthermore, the appropriate marginal tax rate depends on a number of unverifiable aspects of family decision making. Faced with this indeterminacy, we investigate two different measures of the appropriate marginal tax rate. The basic one (denoted RATE) is simply the marginal tax rate that applies to the decedent's taxable estate at death assuming a fixed spousal bequest. Note that after 1981 this procedure assigns a tax rate of zero to a large estate that was entirely left to the surviving spouse. The other tax rate measure, RATEMAX, addresses the issues discussed concerning the treatment of married couples. It is the maximum of RATE and RATESP, where RATESP is equal for married decedents to the marginal tax rate calculated using the bequest to the spouse as the tax base, and is equal to RATE for unmarried individuals. This procedure attempts to implement the idea that the tax distortion faced by the household may be better measured by the tax paid by the second spouse.

\subsubsection{Instrumenting for the Marginal Tax Rate}

As already discussed, a critical methodological challenge is to identify an individual-specific marginal tax rate that is not a function of the estate itself. When studying behavior that is a component of or a deduction from the tax base, such as charitable contributions, this problem has been dealt with by assuming that the other components of the tax base are exogenous (although see, in the context of capital gains realizations, Burman and Randolph 1992), and using the marginal tax rate at zero (or, an average for similar returns) amount of contributions. This "first-dollar" marginal tax rate does not depend on the magnitude of the studied behavior, and is thus exogenous. Because it is not the actual applicable "last-dollar" marginal tax rate, a common empirical strategy is to use the first-dollar marginal tax rate as an instrumental variable for the appropriate last-dollar marginal tax rate.

This approach is much more problematic when the behavior under study is a principal component or, as in this case, is identical to, the tax base. Thus, the literature on the elasticity of 
taxable income (Slemrod 1998) has focused on longitudinal data that bracket changes in the tax schedule. In this way, comparing data over time allows one to look at the behavior at given levels of income but at different marginal tax rates.

Alas, the nature of the estate tax is such that one will never observe the same person paying estate tax under two (or more!) estate tax regimes. In cross-sectional or pooled cross-sectional data, simply regressing the estate value against the marginal estate tax rate will surely produce a bias toward finding a spurious positive relationship, due to the graduated nature of the tax. Consequently, we seek instruments that are correlated with the tax rate, but do not affect independently the estates of taxpayers. In what follows we will use the three tax system measures discussed in Section 4 - TTOP, T100 and T40 - as instruments for the actual marginal tax rate. These instruments vary only across years, and not across individuals in a given year. Thus, using only these instruments would not make use of any cross-sectional variation in identifying the effect of marginal tax rates. This would still be an improvement over the aggregate analysis, however, because we can control for the potentially changing cross-sectional composition of the decedent population, and for potential differential response to taxes.

We can, though, improve upon this approach. In order to make use of the cross-sectional variation, we note that decisions affecting the estate at death are made over the whole lifetime. Consequently, the marginal tax rate should be correlated with characteristics of the tax system in the years preceding death. This adds to our arsenal of potential instruments lagged values of the three measures of the tax (we use ten years lagged values of these variables). More interestingly, it also allows us to construct a set of instruments that vary within a year: the three measures of the tax system in effect when the decedent was 45 . The tax rate at age 45 is chosen to represent the tax rate when individuals begin to consider the ramifications of the estate tax. These instruments vary with age and the year of death of an individual, allowing for a richer source of identification. Furthermore, we include instruments accounting for changes in the taxation of spousal bequests: dummies for married and widowed individuals dying when a limited marital deduction was allowed (1948-1981) and dummies for married and widowed individuals dying when an unlimited marital deduction was allowed (post-1981). 


\subsection{Non-tax Independent Variables}

The estate tax return data contain a number of other variables which might reasonably be expected to affect the estate. ${ }^{21}$ By statistically controlling for these variables, we can presumably sharpen the estimate of the partial effect of taxation on the reported estate. Potentially more importantly, there are several variables which would be expected to moderate the effect of taxation. For example, our theoretical model suggests that the effect of taxes on the estate would depend on age at death. Furthermore, the wealth accumulation of married individuals may differ from the patterns of wealth accumulation among single individuals for reasons unrelated to the tax rates. For example, the effect of uncertainty for a couple will usually be different than the sum of effects for two separate individuals (Hurd 1994). Finally, reported estates may behave in a systematically different way in community property states, in which most family wealth is determined to be jointly owned by both spouses; we include a dummy variable for residence in a community property state. ${ }^{22}$

By including in the regression interaction terms between the tax rates and these other moderating variables, we can enrich our analysis in an important dimension. This is because now in high-tax periods we would expect not only an effect on the level of reported estates, but also an effect on the relative reported estates of decedents with different characteristics. For example, we would expect that in high-tax periods, the reported estates of young decedents would be relatively higher, because the estate tax had not have a chance to affect many years of wealth accumulation decisions.

In order to analyze differential effects by demographic groups, we interact the marginal tax rate with a dummy for being married, sex, age and testate status. Of course, each of these variables interacted with the tax rate is endogenous to the size of the estate, for the same reasons discussed earlier.

\footnotetext{
${ }^{21}$ Although, as discussed above, we have no good indicator of the individual's lifetime income.

${ }^{22}$ Eight states were community property states for the whole period considered: Arizona, California, Idaho, Louisiana, Nevada, New Mexico, Texas and Washington. In 1986 the Uniform Marital Property Act, which approximates community property statutes, was introduced in Wisconsin.
} 


\subsection{Results of Micro Regression Analyses}

\subsubsection{The Basic Regression Framework}

We begin by estimating specifications that are similar to the aggregate ones whose results are reported in Table 1. Table 2 contains the results of a regression of the logarithm of real net worth reported on the estate tax return on the log of the net-of-tax rate (denoted RATE), controlling only for the (economy-wide) variables used in the aggregate analysis. The first column presents the results when the three aggregate tax measures are used as instruments. The coefficient on the net-of-tax rate is equal to -0.05 , and is not significantly different from zero. ${ }^{23}$

The next three columns of Table 2 contain the results of using as the sole instrument one of the three summary measures of the tax rate structure. This specification improves upon the aggregate analysis only by making use of the actual individual tax rates, which allows for an easier interpretation of the estimated coefficient. The estimated elasticities for two of the three instruments are positive, although quite different from the coefficients in the aggregate analysis. However, when T40 (the tax at 40 times the average wealth) is used, the estimated elasticity is negative and significant. One possibility for this anomalous result is that, although asymptotically any instrument will do, the finite sample performance of different instruments may vary. In fact, although the sample contains more than 300,000 individuals, all of the instruments and the righthand side variables are constant within a year, so that this procedure is equivalent to regressing the average logarithm of net worth within the year on the yearly average of the net-of-tax rate and the other explanatory variables. Viewed in this way, there are only as many degrees of freedom as there are years in the sample (49, to be precise), and so finite sample bias may be significant.

A more intriguing explanation has to do with the composition of the sample. By construction, T40 should be most closely related to the marginal tax rates at relatively small estates, while the other two measures should be more correlated with the marginal tax rates at higher estates. If there are systematic differences in how high-wealth and very high-wealth individuals respond to the estate tax (e.g., if the marital status or gender composition of the two groups differ, and

\footnotetext{
${ }^{23}$ We report standard IV errors. Potentially, they may be understated if there is signficant within-year correlation in the error terms. This problem is somewhat alleviated due to inclusion of the time trend and other time-dependent aggregate variables.
} 
the response to the tax varies systematically with these demographic characteristics), different instruments may pick up the response of different groups. Consequently, this result may simply reflect the heterogeneity of response within the sample.

\subsubsection{Introducing Individual-Specific Non-Tax Controls}

Next we introduce into the micro regressions certain known characteristics of the decedents: marital status, sex, testate status, plus age and age squared, and dummy variables for residing in a community property state when married or widowed. ${ }^{24}$ In addition, we include the set of variables from Table 2 and the values of the S\&P 500 index lagged by 5 years, 10 years and at the time the decedent was $45 .{ }^{25}$ This last variable is of particular interest, because it may help to control for any cohort effect and to disentangle cohort and age effects. A similar approach is taken in Kapteyn, Alessie and Lusardi (1999) in their study of the effect of Social Security programs on saving. They consider different indicators of economic conditions during the economic life of an individual: GNP per capita when the household entered the labor market (proxying for productivity changes), as well as changes in the social security system. Although these factors may be relevant for the general public, they are probably of less importance for the very rich group that we are studying. For this segment of population, the performance of financial markets is probably of more relevance. In addition, the level of the stock market index helps to control for the endowment of different cohorts. It is also undoubtedly affected by productivity shocks, so that this aspect is not completely absent from our analysis. ${ }^{26}$

Table 3 shows the results of the regression specifications in which the only measure of the tax burden is the marginal tax rate at the time of death. For comparison with aggregate regressions, the first column presents the results when only the three tax measures are used as the instruments. The next two specifications extend the set of instruments, first by adding the lagged and at age 45

\footnotetext{
${ }^{24}$ Because most demographic information is unavailable before 1925, these results (and those of the later tables) are based on returns of decedents in 1925 and thereafter.

${ }^{25}$ Although not reported in the tables, we also controlled separately for a dummy indicating the imputation of age, (equal zero if not imputed), imputed age squared, and the S\&P 500 at age of 45 multiplied by the age imputation dummy. The results are robust to limiting the sample to just individuals for whom the age at death is known.

${ }^{26}$ We do not include the level of GNP in our analysis, because there is no consistent annual series going back to the $19^{\text {th }}$ century, when the economic life of many individuals in our sample began.
} 
tax measures, and then by additionally including the marital deduction dummies. The estimated elasticity with respect to the net-of-tax rate is between -0.11 and 0.09 . It is negative and significant when smaller sets of instruments are used, and becomes positive when the full set of instruments is used. We conclude that the estimated relationship between the reported estate and the marginal estate tax rate is quite fragile to the set of instruments used to try to disentangle the behavioral response from the mechanical positive relationship between the size of the estate and the marginal tax rate that arises due to graduated nature of the tax system.

The estimated values on the other coefficients are of separate interest. The estimated coefficients on age and age squared correspond to an increasing wealth profile with people who are 70 years old having approximately $4.7 \%$ higher net worth than those who are 50 . This pattern is consistent with some other empirical evidence (e.g., Hurd 1987). Most of the other variables enter significantly as well. Estimated values of the marital status coefficients ${ }^{27}$ suggest that being divorced is associated with a relatively higher level of net worth on the estate, while being single is on average accompanied by lower net worth, when compared to other types of marital status. Being a male is associated with slightly higher reported net worth. Testate status has the strongest effect in explaining net worth of all the dummy variables. People who die with a will have a net worth that is on average $27 \%$ higher than of those who die intestate. This is consistent with the idea that the presence of a will is a good indicator of having a bequest motive. It is also plausible that having a will is more attractive when the estate tax is higher, and so is an endogenous variable.

The S\&P 500 index at the age of 45 enters significantly and with the expected positive sign. The estimated elasticity is, however, rather small. The elasticity with respect to the current level of the S\&P 500 index is estimated to be about 0.25 , not too far from the effect estimated earlier. Surprisingly, lagged values of the S\&P 500 index enter negatively. It is possible that this reflects tax avoidance. The higher is net worth, the more important estate tax planning becomes, because higher estate tax rates may potentially apply to it. Shocks to net worth (e.g., due to a booming stock market) may then induce an avoidance response and result in lower observed net worth a few years later.

The logarithm of the death rate is not significantly related to net worth reported on estate

\footnotetext{
${ }^{27}$ The dummy for being single is the omitted marital status category.
} 
tax returns. Aggregate wealth may control for the unobservable endowment, in which case the positive coefficient is not surprising. The estimated negative effect of lagged income inequality is unexpected, although it is consistent with some of the aggregate results. The estimated effects of the lagged income tax rate variables are consistent with the aggregate results.

\subsubsection{Allowing for Heterogeneity in the Response to Taxation}

Table 4 presents the results of specifications that allow for differential response to the estate tax for different groups of taxpayers. The first specification reveals no differential response by sex. The next three specifications, which test for differential response by marital status, testate status, and age, are all of interest.

As mentioned earlier, the response of married couples may differ from the response of single individuals. This can occur because the expected longevity of a family (understood as the survival of one of the spouses) is higher than that of an individual. Consequently, the probability of a family paying the tax in any given period is smaller, and therefore the shape of its consumption profile is less affected. A family may also respond to the tax by modifying the timing of its taxable estates. Higher tax rates are usually associated with more progressive rate structures, and thus introduce a stronger motive to equate the expected marginal tax rate (and therefore the estate) of both spouses. The second specification in Table 4, which allows for a differential response by marital status, suggests that the married individuals (i.e., these with a surviving spouse) respond to a lower net-of-tax rate by increasing their net worth (with an elasticity of -0.078), while the effect for single individuals is insignificant. This may be explained by the hypothesis of equalization of the marginal tax rates if, absent the tax, the report of the first spouse would be smaller than that of the second. Then, the tax rate of the first spouse, ceteris paribus, is negatively correlated with the tax rate of the second spouse. If so, the estimated negative coefficient for the married individuals may be consistent with reduction of the family's net worth in response to taxes.

Theory indicates clearly that the response of the estate to the tax rate is greater the larger the time one has to adjust to the tax rate. This may be crudely captured by interacting the marginal tax rate with age. Such a regression is presented in the third specification of Table 4. As expected, the tax effect is increasing with age. 
Finally, in the last column of Table 4 we report the results of interacting testate status with the net-of-tax rate. If, as is highly plausible, having a will is an indication of a bequest motive, one would expect that wealth accumulation would be more sensitive to taxation for those who die with a will. The results strongly confirm this expectation, although as noted earlier this conclusion must be tempered by the possible endogeneity of testate status.

\subsubsection{Alternative Measures of the Effective Tax Rate}

The marginal estate tax rate variable we have analyzed up to this point is evaluated at the time of death. However, the bulk of the behavioral response to estate taxation undoubtedly takes place in the years preceding death, perhaps throughout the whole economic life of an individual. Thus, arguably it is the tax structure in place during the life of an individual that affects the expectations about the actual tax at death and shapes the response. We investigate two measures of the tax rate expected earlier in life: the tax rate 10 years before death (RATE10) and at the age of 45 (RATE45). Both are calculated by applying the relevant tax structure to the actual taxable estate at death denominated in dollars of the corresponding year. Table 5 shows the results. Each of these net-of-tax variables has a positive and significant impact on the reported estate. Furthermore, in results not reported here, in a "horserace" between either of these variables and the basic rate, the alternative measure robs the basic tax rate of its significance and has a significant positive coefficient. These results are consistent with the idea that most of the behavioral response takes place over a long horizon, and suggests that future research should focus on such measures of the tax incentives.

The last variable we investigated is RATEMAX, equal to the maximum of the own and an estimated spousal tax rate for married individuals, and equal to the decedent's own marginal tax rate for unmarried individuals. ${ }^{28}$ The estimated coefficient is significantly negative. This finding may simply reflect the impact on the timing of spousal bequests discussed earlier, or may indicate that RATEMAX does not successfully measure the expected effective tax rate of a married couple. For example, holding other things constant, the spousal bequest will be higher the lower is the

\footnotetext{
${ }^{28}$ Because of the unavailability of spousal bequests before 1945 , this specification is estimated for the post-WW II years only.
} 
marginal tax rate faced by the spouse. Consequently, the estimated negative value may be spurious. Understanding the effect of the estate tax on spousal bequests, and how empirical investigation might account for this, should be high on the agenda for future research.

\section{Conclusions}

This paper represents a first attempt to learn from an extraordinary archive for estate tax return data. In the end we have, as first attempts usually do, raised as many questions as we have provided answers. We began with an aggregate time-series analysis, and found that summary measures of the estate tax rate structure are generally negatively correlated with the reported net worth of the top estates relative to national wealth. This conclusion is preserved when we control for other relevant influences in a multiple regression framework. This finding is consistent with estate taxation reducing either wealth accumulation or inducing avoidance, or both. We view this evidence as suggestive rather than definitive, because of the difficulty of controlling for other factors and of ascribing causality to an observed association.

We then turned to an analysis of the individual tax return data. We make use of both the timeseries variation in the tax rate structure, and the cross-sectional variation in observable individual characteristics. In particular, cross-sectional differences in age provide a potentially important source of identification because they correspond to differences in the tax structure effective during one's lifetime.

In our baseline specification the estimated elasticity of reported estates is positive (i.e., negative with respect to the tax rate itself) and statistically significant. The response is also clearly positive for those who die testate and are older, which suggests that a behavioral response is present for older people who have a bequest motive.

When we investigate measures of the tax rate that prevailed during one's lifetime rather than at death, the estimated negative behavioral response to estate taxes is more pronounced. In particular, the marginal tax rate at the age of 45 dominates all other measures, and the estimated elasticity with respect to (one minus) the tax rate is 0.16 , and is statistically significant. Such a number is also economically significant, because it implies that an estate tax rate of $50 \%$ would 
reduce the reported net worth of the richest half percent of the population by $10.5 \%$ when its effect is fully realized many years later. ${ }^{29}$

Our results do not answer the question of whether the estate tax deserves a role in the U.S. tax system. They are, though, a first step toward pinning down the magnitude of behavioral response to the tax, which is a crucial input for determining the optimal level of estate taxes. ${ }^{30}$ A part of the measured effect on reported estates is due to reduced wealth accumulation, and another part is due to estate planning techniques. Only the former has implications for capital accumulation, although both are indicative of economic cost. Note, though, that to those who believe that a highly unequal distribution of wealth has negative consequences aside from its implications for individual levels of well-being, that the estate tax reduces the wealth accumulation of the most well-off families is an indication of policy success rather than policy failure. However, as discussed by Kaplow (this volume), that is a controversial notion.

\footnotetext{
${ }^{29}$ The change in the log of net worth is $0.16 \ln (1-.5) \approx-0.111$, which corresponds to a reduction in net worth by $1-\exp (-0.111) \approx 10.5 \%$.

${ }^{30}$ See Kopczuk (2000) for a theoretical analysis of this question.
} 


\section{A Aggregate Data}

To construct the aggregate estate-wealth ratio, estratio, we first calculate the number of total decedents in a given year using the mortality rates and the population from U.S. Bureau of the Census (1975) (for data before 1968) and from the Economic Report of the President (for after 1968). Using this information, we sum the net worth of the number of estates that is equal to $0.5 \%$ of total decedents with the highest net worth. After 1945, we use the population weights to calculate the size of the population represented by a given sample of estates. Between 1962 and 1976, the sample is representative of returns filed in the next year, so that calculated net worth corresponds to this population. This procedure gives us the total reported estates of the top $0.5 \%$ of decedents, all of whom are subject to the estate taxation over this period.

The denominator of estratio, aggregate economy-wide net worth, is based on a few sources. Up to and including 1945, it is taken from Goldsmith, Brady and Menderhausen (1956, table W-1), with minor corrections for some years as in U.S. Bureau of the Census (1975, series F422) (the latter source does not contain the data for all years). After 1945, the data on net worth is taken from the Federal Reserve balance sheets of the U.S. economy. Both series are calculated at current cost. The series overlap between 1945 and 1958. They are very close for most of this period, although there is a discrepancy of approximately $10 \%$ for 1945 . In calculating average wealth, we use the total U.S. population.

The series for the Consumer Price Index and the Standard and Poor's 500 Index are from U.S. Bureau of the Census (1975) (series E135) and the Economic Report of the President (1999).

The series on income inequality are based on two sources. Up to 1945, we use the share of income going to the top $5 \%$ of the richest individuals, constructed by Simon Kuznets and reprinted in U.S. Bureau of the Census (1975). After 1945, we use the share of income going to the top 5\% families, constructed by the Bureau of Census (U.S. Bureau of the Census 1996). The values of the two series are very close in the overlapping year of 1945 . We are not aware of any consistent series for income inequality for the whole period that we consider.

The information on the estate tax structure is obtained from the Internal Revenue Code. ${ }^{31}$

\footnotetext{
${ }^{31}$ Luckey (1995) and McCubbin (1990) discuss the history of changes in the taxation of estates.
} 
The series for the top tax rate ${ }^{32}$ and tax rates at the standardized levels of wealth are constructed based on the actual tax structures. For the years when more than one tax law was in effect, we use a weighted average of the relevant tax rates under different regimes, with weights proportional to the time a given tax structure was in place. The Tax Reform Act of 1924 was repealed in 1926, so that estates of individuals who died between 1924 and 1926 were retroactively subject to the rates set before 1924. For these years the relevant tax structure is unclear, because repeal of the law was probably expected for part of this period. Nevertheless, we use the marginal tax rates that were effective during this period. In calculating the lagged tax rates, tax rate series are set to zero before 1916, although there were episodes when there was an estate tax, e.g., in the years 1898-1902, when the death tax introduced by the War Revenue Act of 1898 was in effect. However, we assume that these taxes were expected to last for a short period of time only, so that they did not have an effect on the lifetime decisions of people who were young at the time.

\section{B Micro Data}

The basic data are drawn from the estate tax returns collected by the IRS. The database contains data from the Statistics of Income studies for 1916 to 1945, 1962, 1965, 1969, 1972, 1976 and for each year from 1982 to $1996 .{ }^{33}$ The pre-war data contains a nearly $100 \%$ sample of estate tax returns for people who died between 1916 and $1945 .{ }^{34}$ The post-war data are stratified samples of estate tax returns. Between 1962 and 1976 they are representative of the estates filed in one year following the nominal date of the study, resulting in a majority of the returns being for decedents who died in the year of the study. Starting in 1982, they are stratified to be representative of the population of decedents in a given year. We use the sampling weights in our regression.

\footnotetext{
${ }^{32}$ This is defined as the marginal tax rate for the largest estate, not the maximum marginal tax rate. Due to the phase-out of the initial deduction after 1987 the latter is $60 \%$, while the former is $55 \%$.

${ }^{33}$ The pre-1945 data are described in McCubbin (1990), and the later data are described in various studies in Johnson (1994).

${ }^{34}$ There is a possibility that some of the returns were missing at the time the data was coded. However, McCubbin (1990) compared the number of returns present in the sample to the numbers reported by the IRS in its official publications from this period, and concluded that the coverage is extremely good. In fact, in some years the dataset contains more returns than the IRS reported.
} 
The estate tax return data contain almost all the items on the tax return, but the tax form changed over the years so that only a subset of variables is present for all observations. With some exceptions, this subset includes the year of death, debts and mortgages, gross estate, charitable bequests, sex, marital status, testate status, and the presence of trust and gifts. ${ }^{35}$ The pre-1945 data contain information on the number of children and the number of beneficiaries. The pre-1945 data and data for 1976 contain the length of the terminal illness. The post-war data additionally contain information on the size of the taxable estate, bequests to a surviving spouse and any deduction for such bequests.

We define net worth to be the total gross estate minus debts reported on the tax returns. Notably, before 1945 data set does not contain information on the estate subject to taxation, a natural subject of investigation. Although there is information about the total tax liability owed to the federal government, there is no information about the deductions for taxes already paid, such as the state estate, inheritance and gift taxes, that were used to arrive at this number, making it impossible to calculate the taxable estate by inverting the tax liability using the actual tax structure. ${ }^{36}$ Instead, we construct a measure of taxable income based on other information. As our measure of taxable estate before 1918, we simply take net worth. In 1918, the deduction for charitable bequests was introduced. It applies to estates of decedents who died after December 31, 1917, and thus we define taxable estate to be equal to the difference between net worth and charitable contributions. ${ }^{37}$ This measure ignores other deductions about which we have no information. The main missing components are deductions for the tax paid on property subject to the estate tax within previous 5 years and administrative funeral expenses. After 1945, we use the actual adjusted taxable estate from the tax return. In the years 1962 to 1981 the marital deduction is

\footnotetext{
${ }^{35}$ When the marital status is missing in the regression analyses, we treat it as a separate category. Age is missing in 1965 and for some observations in other years.

${ }^{36}$ For example, under the Revenue Act of 1926 estates were allowed a tax credit not to exceed 80 percent of the total federal estate tax for estate, inheritance, legacy, or succession taxes paid to any of the several states, territories or the District of Columbia. Before 1924 this credit was limited to 25 percent of the total liability, and when the tax was introduced in 1916 no credit was allowed. Furthermore, no credit was allowed against so-called, "additional taxes" introduced by the Revenue Act of 1932, which constituted most of the tax liability. After 1926, estates were allowed a tax credit for gift taxes paid. This was a significant item, for example, for the returns filed in 1934, as it constituted $11 \%$ of the total tax liability.

${ }^{37}$ This change was retroactive, but we do not account for that aspect.
} 
present on the tax return, and after 1981 it is equal to the spousal bequest. Before 1948, there was no marital deduction.

The marginal tax rates are constructed by applying the actual tax structure at the time of death to the (constructed) taxable estate. Tax rates at the age of 45 and 10 years before death are constructed by applying the tax structure in the relevant year (in effect on the same day of that year) to the actual taxable estate at the time of death denominated in the dollars for that year (deflated using the CPI). For decedents younger than 45, we use the actual tax rate at death as the tax rate at age 45 .

Marital status is missing for $20 \%$ of the returns (and it is missing for all observations in 1965). The rest of decedents are classified as either married (43\%), widowed (27\%), single (8\%), separated $(0.1 \%)$ or divorced $(1.7 \%)$. We make use of separate dummies for each type of marital status, and omit the dummy for being single.

Age is present for $88 \%$ of the sample. It is missing for all individuals who filed their returns in 1969, and for some subset of the remaining population. To avoid deleting these observations, we impute their age. This is done by regressing age on a constant and a time dummy for the rest of the population and using predicted values for the individuals with missing age. ${ }^{38}$ In our regression we include as a separate variable a dummy for age being imputed, as well as a variable which is equal to the imputed age for individuals with missing age, and zero otherwise. We follow the same procedure for variables that were constructed using age (such as the tax rate at age of 45 and interactions of the tax rate with age). The coefficients on these variables are insignificant and are not reported. Most of our specifications were also run on the sample of individuals with a reported age. The results are not significantly different than the ones reported here.

Two other variables are present for the whole sample. The dummy variable for sex takes the value of one for men, who constitute $68 \%$ of the sample. $87 \%$ of the individuals are testate.

\footnotetext{
${ }^{38}$ The predicted age in 1917 was 65.8 and the coefficient on the time dummy was .13 .
} 


\section{References}

Abel, Andrew B., "Precautionary Saving and Accidental Bequests," American Economic Review, September 1985, 75 (4), 777-791.

and Mark Warshawsky, "Specification of the Joy of Giving: Insights from Altruism," Review of Economics and Statistics, February 1988, 70 (1), 145-149.

Andreoni, James, "Impure Altruism and Donations to Public Goods: A Theory of Warm-Glow Giving," Economic Journal, June 1990, 100 (401), 464-477.

Barro, Robert J., "Are Government Bonds Net Wealth?," Journal of Political Economy, November-December 1974, 82 (6), 1095-1117.

_ and James W. Friedman, "On Uncertain Lifetimes," Journal of Political Economy, August $1977,85(4), 843-49$.

Bernheim, B. Douglas, "How Strong Are Bequest Motives? Evidence Based on Estimates of the Demand for Life Insurance and Annuities," Journal of Political Economy, October 1991, $99(5), 899-927$.

_ _ "Rethinking Savings Incentives," in Alan J. Auerbach, ed., Fiscal Policy: Lessons from Economic Research, Cambridge and London: MIT Press, 1997.

_ Andrei Shleifer, and Lawrence H. Summers, "The Strategic Bequest Motive," Journal of Political Economy, December 1985, 93 (6), 1045-76.

Blundell, Richard and Thomas E. MaCurdy, "Labor Supply: A Review of Alternative Approaches," in Orley Ashenfelter and David Card, eds., Handbook of Labor Economics, Vol. 3, Amsterdam; New York: Elsevier/North Holland, 1999.

Burman, Leonard E. and William C. Randolph, "Measuring Permanent Responses to Capital-Gains Tax Changes in Panel Data," American Economic Review, September 1992, $84(4), 794-809$.

Carroll, Christopher D., "Why Do the Rich Save So Much?" In Slemrod (2000). 
Chapman, Kenneth, Govind Hariharan, and Lawrence Southwick, "Estate Taxes and Asset Accumulation," Family Business Review, 1996, 9 (3), 253-68.

Davies, James B., "Uncertain Lifetime, Consumption, and Dissaving in Retirement," Journal of Political Economy, June 1981, 89 (3), 561-77.

Eller, Martha, Brian Erard, and Chih-Chin Ho, "The Magnitude and Determinants of Federal Estate Tax Noncompliance," this volume.

Eller, Martha Britton and Barry W. Johnson, "Using a Sample of Federal Estate Returns to Examine the Effects of Audit Revaluation on Pre-Audit Estimates," Proceedings of the 1999 Meeting of the American Statistical Association, Section on Government Statistics, forthcoming.

Erard, Brian, "Estate Tax Underreporting Gap Study: A Report Prepared for the Internal Revenue Service Economic Analysis and Modeling Group," TIRNO-98-P-00406, Internal Revenue Service 1999.

Feenberg, Daniel R. and James M. Poterba, "Income Inequality and the Incomes of Very High-Income Taxpayers: Evidence from Tax Returns," in James M. Poterba, ed., Tax Policy and the Economy, Vol. 7, National Bureau of Economic Research, The MIT Press, 1993.

Fiekowsky, Seymour, "The Effect on Saving of the United States of Estate and Gift Tax," in Carl S. Shoup, ed., Federal Estate and Gift Taxes, Washington: Brookings Institution, 1966.

Gale, William G. and Maria G. Perozek, "Do Estate Taxes Reduce Savings?," this volume.

Goldsmith, Raymond W., Dorothy S. Brady, and Horst Menderhausen, A Study of Saving in the United States, Vol. III, Princeton, New Jersey: Princeton University Press, 1956.

Gordon, Roger H. and Joel Slemrod, "Are "Real" Responses to Taxes Simply Income Shifting Between Corporate and Personal Tax Bases?" In Slemrod (2000). 
Hubbard, R. Glenn, Jonathan Skinner, and Stephen P. Zeldes, "The Importance of Precautionary Motives in Explaining Individual and Aggregate Saving," Carnegie-Rochester Conference Series on Public Policy, June 1994, 40, 59-125.

Hurd, Michael D., "Savings of the Elderly and Desired Bequests," American Economic Review, June 1987, 77 (3), 298-312.

, "Mortality Risk and Bequests," Econometrica, July 1989, 57 (4), 779-813.

_ - "Measuring the Bequest Motive: The Effect of Children on Saving by the Elderly in the United States," in Toshiaki Tachibanaki, ed., Savings and Bequests, Ann Arbor: University of Michigan Press, 1994, pp. 111-136.

Johnson, Barry W., ed., Compendium of Federal Estate Tax and Personal Wealth Studies, Department of Treasury, Internal Revenue Service, 1994. Pub. 1773 (4-94).

Joulfaian, David, "Charitable Bequests and Estate Taxes: Another Look at the Evidence," November 1998. Office of Tax Analysis, U.S. Department of Treasury, mimeo.

_ _ "The Federal Estate and Gift Tax: Description, Profile of Taxpayers and Economic Consequences," Office of Tax Analysis Paper 80, U.S. Department of Treasury, 1998.

Kaplow, Louis, "Arguments For and Against Estate and Gift Taxation," this volume.

Kapteyn, Arie, Rob Alessie, and Annamaria Lusardi, "Explaining the Wealth Holdings of Different Cohorts: Productivity Growth and Social Security," August 1999. Mimeo.

Kopczuk, Wojciech, "On Redistribution Using Estate Taxation," January 2000. University of Michigan, mimeo.

Kotlikoff, Laurence J. and Avia Spivak, "The Family as an Incomplete Annuities Market," Journal of Political Economy, April 1981, 89 (2), 372-81.

Laitner, John, "Intergenerational and Interhousehold Economic Links," in Mark K. Rosenzweig and Oded Stark, eds., Handbook of Population and Family Economics, Vol. 1A, Amsterdam; New York: Elsevier/North Holland, 1997. 
Luckey, John R., "A History of Federal Estate, Gift and Generation-Skipping Taxes," CRS Report for Congress 95-444A, Congressional Research Service March 1995.

McCubbin, Janet G., "The Intergenerational Wealth Study: Basic Estate Data 1916-1945," Statistics of Income Bulletin, Spring 1990.

Poterba, James M., "The Estate Tax and After-Tax Investment Returns." In Slemrod (2000).

Richard, Scott F., "Optimal Consumption, Portfolio and Life Insurance Rules for an Uncertain Lived Individual in a Continuous Time Model," Journal of Financial Economics, June 1975, $2(2), 187-203$.

Sandford, Cedric, Economics of Public Finance, Third ed., Oxford: Pergamon Press, 1984.

Slemrod, Joel, "High-Income Families and the Tax Changes of the 1980s: The Anatomy of Behavioral Response," in Martin S. Feldstein and James M. Poterba, eds., Empirical Foundations of Household Taxation, Chicago and London: The University of Chicago Press, 1996, pp. 169-189.

__ , "Methodological Issues in Measuring and Interpreting Taxable Income Elasticities," National Tax Journal, December 1998, 51 (4).

__ , "A General Model of the Behavioral Response to Taxation," International Tax and Public Finance, forthcoming.

, ed., Does Atlas Shrug? The Economic Consequences of Taxing the Rich, New York: Harvard University Press and Russell Sage Foundation, 2000.

Strawczynski, Michel, "Government Intervention as a Bequest Substitute," Journal of Public Economics, March 1994, 53 (3), 477-95.

Tait, Alan A., The Taxation of Personal Wealth, Urbana: University of Illinois Press, 1967.

U.S. Bureau of the Census, Historical Statistics of the United States, Colonial Times to 1970, Washington, D.C.: U.S. Bureau of the Census, 1975. 
_, "Historical Income Tables — Families, Table F.2 Share of Aggregate Income Received by Each Fifth and Top 5 Percent of Families (All Races)," October 41996. http://www.census.gov/hhes/income/histinc/f02.html.

U.S. Joint Economic Committee, The Economics of the Estate Tax, 98-J-842-48, December 1998.

Wolff, Edward N., "Discussant's Comments on Douglas Holtz-Eakin, 'The Uneasy Case for Abolishing the Estate Tax'," Tax Law Review, 1996, 51 (3), 517-22.

Yaari, Menahem E., "Uncertain Lifetime, Life Insurance, and the Theory of the Consumer," Review of Economic Studies, April 1965, 32 (2), 137-150. 
Table 1: Aggregate Time-Series Results: The Effect of the Estate Tax Rate on the Reported Estate/Wealth Ratio

\begin{tabular}{|c|c|c|c|c|c|c|}
\hline Independent Variable & I & II & III & IV & $\mathrm{V}$ & VI \\
\hline $\begin{array}{l}\text { log top net-of-tax } \\
\text { rate (1-TTAX) }\end{array}$ & $\begin{array}{r}0.075 \\
(0.069)\end{array}$ & & & $\begin{array}{r}0.083 \\
(0.027)\end{array}$ & & \\
\hline $\log (1-\mathrm{T} 100)$ & & $\begin{array}{r}0.657 \\
(0.130)\end{array}$ & & & $\begin{array}{r}0.245 \\
(0.115)\end{array}$ & \\
\hline $\log (1-\mathrm{T} 40)$ & & & $\begin{array}{r}0.717 \\
(0.104)\end{array}$ & & & $\begin{array}{r}0.335 \\
(0.171)\end{array}$ \\
\hline $\begin{array}{l}\text { max log ( } 1 \text {-income tax } \\
\text { rate) (10 year lag) }\end{array}$ & $\begin{array}{r}-0.263 \\
(0.034)\end{array}$ & $\begin{array}{r}-0.155 \\
(0.035)\end{array}$ & $\begin{array}{r}-0.132 \\
(0.031)\end{array}$ & $\begin{array}{r}-0.045 \\
(0.019)\end{array}$ & $\begin{array}{r}-0.046 \\
(0.020)\end{array}$ & $\begin{array}{r}-0.060 \\
(0.022)\end{array}$ \\
\hline $\begin{array}{l}\max \log (1 \text {-corporate tax } \\
\text { rate) (10 year lag) }\end{array}$ & $\begin{array}{r}1.375 \\
(0.385)\end{array}$ & $\begin{array}{r}0.717 \\
(0.268)\end{array}$ & $\begin{array}{r}0.921 \\
(0.195)\end{array}$ & $\begin{array}{r}0.452 \\
(0.163)\end{array}$ & $\begin{array}{r}0.709 \\
(0.133)\end{array}$ & $\begin{array}{r}0.906 \\
(0.140)\end{array}$ \\
\hline log real S\&P 500 & $\begin{array}{r}0.234 \\
(0.054)\end{array}$ & $\begin{array}{r}0.227 \\
(0.043)\end{array}$ & $\begin{array}{r}0.307 \\
(0.038)\end{array}$ & $\begin{array}{r}0.443 \\
(0.024)\end{array}$ & $\begin{array}{r}0.414 \\
(0.032)\end{array}$ & $\begin{array}{r}0.418 \\
(0.032)\end{array}$ \\
\hline $\begin{array}{l}\text { log inequality } \\
\text { (10 year lag) }\end{array}$ & $\begin{array}{r}0.512 \\
(0.400)\end{array}$ & $\begin{array}{r}0.252 \\
(0.193)\end{array}$ & $\begin{array}{r}0.182 \\
(0.167)\end{array}$ & $\begin{array}{r}-0.100 \\
(0.152)\end{array}$ & $\begin{array}{r}-0.408 \\
(0.114)\end{array}$ & $\begin{array}{r}-0.372 \\
(0.119)\end{array}$ \\
\hline $\begin{array}{l}\text { log real aggregate } \\
\text { wealth per capita }\end{array}$ & & & & $\begin{array}{r}-0.805 \\
(0.113)\end{array}$ & $\begin{array}{r}-0.720 \\
(0.115)\end{array}$ & $\begin{array}{r}-0.616 \\
(0.125)\end{array}$ \\
\hline log death rate & & & & $\begin{array}{r}-0.735 \\
(0.118)\end{array}$ & $\begin{array}{r}-0.715 \\
(0.128)\end{array}$ & $\begin{array}{r}-0.701 \\
(0.132)\end{array}$ \\
\hline time trend & & & & $\begin{array}{r}-0.005 \\
(0.002)\end{array}$ & $\begin{array}{r}-0.003 \\
(0.003)\end{array}$ & $\begin{array}{r}-0.002 \\
(0.003)\end{array}$ \\
\hline constant & $\begin{array}{r}-2.913 \\
(1.267) \\
\end{array}$ & $\begin{array}{r}-2.020 \\
(0.648) \\
\end{array}$ & $\begin{array}{r}-1.990 \\
(0.564) \\
\end{array}$ & $\begin{array}{r}7.038 \\
(0.996) \\
\end{array}$ & $\begin{array}{r}7.326 \\
(1.044) \\
\end{array}$ & $\begin{array}{r}6.307 \\
(1.198) \\
\end{array}$ \\
\hline $\bar{R}^{2}$ & 0.88 & 0.92 & 0.94 & 0.98 & 0.98 & 0.98 \\
\hline$N$ & 49 & 49 & 49 & 49 & 49 & 49 \\
\hline Modified DW & 0.72 & 0.96 & 1.04 & 2.18 & 2.07 & 1.93 \\
\hline
\end{tabular}

Notes:

The dependent variable is the logarithm of estratio, as defined in text.

Standard errors are in parentheses.

The Durbin-Watson statistic is calculated using only adjacent observations, i.e., using 44 out of 49 observations. 
Table 2: Pooled Cross-Section Regression Results with Alternative Instrument Sets: The Effect of the Estate Tax on Reported Net Worth

\begin{tabular}{|c|c|c|c|c|}
\hline \multirow[t]{2}{*}{ Independent Variable } & \multicolumn{4}{|c|}{ Instruments } \\
\hline & All & TTAX & $\mathrm{T} 100$ & $\mathrm{~T} 40$ \\
\hline $\log (1-\mathrm{RATE})$ & $\begin{array}{r}-0.051 \\
(0.038)\end{array}$ & $\begin{array}{r}0.027 \\
(0.042)\end{array}$ & $\begin{array}{r}1.024 \\
(0.114)\end{array}$ & $\begin{array}{r}-0.277 \\
(0.050)\end{array}$ \\
\hline $\begin{array}{l}\max \log (1 \text {-income tax } \\
\text { rate) }(10 \text { year lag })\end{array}$ & $\begin{array}{r}-0.071 \\
(0.005)\end{array}$ & $\begin{array}{r}-0.074 \\
(0.005)\end{array}$ & $\begin{array}{r}-0.111 \\
(0.006)\end{array}$ & $\begin{array}{r}-0.063 \\
(0.005)\end{array}$ \\
\hline $\begin{array}{l}\max \log (1-\text { corporate } \\
\text { tax rate) }(10 \text { year lag) }\end{array}$ & $\begin{array}{r}0.456 \\
(0.028)\end{array}$ & $\begin{array}{r}0.440 \\
(0.028)\end{array}$ & $\begin{array}{r}0.236 \\
(0.038)\end{array}$ & $\begin{array}{r}0.502 \\
(0.028)\end{array}$ \\
\hline $\log$ real S\&P 500 & $\begin{array}{r}0.341 \\
(0.006) \\
\end{array}$ & $\begin{array}{r}0.337 \\
(0.006) \\
\end{array}$ & $\begin{array}{r}0.282 \\
(0.009) \\
\end{array}$ & $\begin{array}{r}0.354 \\
(0.006) \\
\end{array}$ \\
\hline log inequality (10 year lag) & $\begin{array}{c}-0.304 \\
(0.030)\end{array}$ & $\begin{array}{r}-0.269 \\
(0.031)\end{array}$ & $\begin{array}{r}0.178 \\
(0.058)\end{array}$ & $\begin{array}{r}-0.405 \\
(0.033)\end{array}$ \\
\hline $\begin{array}{l}\text { log real aggregate } \\
\text { wealth per capita }\end{array}$ & $\begin{array}{r}0.284 \\
(0.025)\end{array}$ & $\begin{array}{r}0.283 \\
(0.025)\end{array}$ & $\begin{array}{r}0.269 \\
(0.028)\end{array}$ & $\begin{array}{r}0.287 \\
(0.024)\end{array}$ \\
\hline log death rate & $\begin{array}{r}-0.926 \\
(0.027)\end{array}$ & $\begin{array}{r}-0.906 \\
(0.028)\end{array}$ & $\begin{array}{r}-0.642 \\
(0.041)\end{array}$ & $\begin{array}{r}-0.986 \\
(0.028)\end{array}$ \\
\hline time trend & $\begin{array}{r}-0.005 \\
(0.001)\end{array}$ & $\begin{array}{r}-0.004 \\
(0.001)\end{array}$ & $\begin{array}{r}0.007 \\
(0.001)\end{array}$ & $\begin{array}{r}-0.008 \\
(0.001)\end{array}$ \\
\hline constant & $\begin{array}{c}12.398 \\
(0.238)\end{array}$ & $\begin{array}{r}12.250 \\
(0.242) \\
\end{array}$ & $\begin{array}{r}10.339 \\
(0.334) \\
\end{array}$ & $\begin{array}{r}12.831 \\
(0.242)\end{array}$ \\
\hline $\bar{R}^{2}$ & 0.1952 & 0.1931 & 0.1631 & 0.2007 \\
\hline$N$ & 309,136 & 309,136 & 309,136 & 309,136 \\
\hline
\end{tabular}

Notes:

The dependent variable is the logarithm of net worth in 1945 dollars.

Standard errors are in parentheses.

The set of instruments includes the top tax rate, the tax rates at 100 times average wealth, and at 40 times average wealth (all expressed as the logarithms of one minus the rate). 
Table 3: Pooled Cross-Section Regression Results with Decedent Characteristics and Alternative Sets of Instruments

\begin{tabular}{|c|c|c|c|}
\hline Independent Variable & I & II & III \\
\hline $\log (1-\mathrm{RATE})$ & $\begin{array}{r}-0.084 \\
(0.051)\end{array}$ & $\begin{array}{r}-0.110 \\
(0.040)\end{array}$ & $\begin{array}{r}0.094 \\
(0.024)\end{array}$ \\
\hline $\begin{array}{l}\max \text { log ( } 1 \text {-income tax } \\
\text { rate) (10 year lag) }\end{array}$ & $\begin{array}{r}-0.047 \\
(0.007)\end{array}$ & $\begin{array}{r}-0.045 \\
(0.007)\end{array}$ & $\begin{array}{r}-0.062 \\
(0.006)\end{array}$ \\
\hline $\begin{array}{l}\max \log (1-\text { corporate } \\
\text { tax rate) }(10 \text { year lag })\end{array}$ & $\begin{array}{r}0.199 \\
(0.039)\end{array}$ & $\begin{array}{r}0.197 \\
(0.039)\end{array}$ & $\begin{array}{r}0.212 \\
(0.039)\end{array}$ \\
\hline $\begin{array}{l}\max \log (1 \text {-income tax } \\
\text { rate) (at age } 45)\end{array}$ & $\begin{array}{r}0.002 \\
(0.005)\end{array}$ & $\begin{array}{r}0.004 \\
(0.005)\end{array}$ & $\begin{array}{r}-0.008 \\
(0.004)\end{array}$ \\
\hline $\begin{array}{l}\max \log (1 \text {-corporate } \\
\text { tax rate) (at age } 45)\end{array}$ & $\begin{array}{r}0.045 \\
(0.020)\end{array}$ & $\begin{array}{r}0.042 \\
(0.019)\end{array}$ & $\begin{array}{r}0.065 \\
(0.019)\end{array}$ \\
\hline Age & $\begin{array}{r}-0.001 \\
(0.001)\end{array}$ & $\begin{array}{r}-0.001 \\
(0.001)\end{array}$ & $\begin{array}{r}-0.001 \\
(0.001)\end{array}$ \\
\hline Age2 & $\begin{array}{r}0.00002 \\
(0.000007)\end{array}$ & $\begin{array}{r}0.00002 \\
(0.000007)\end{array}$ & $\begin{array}{r}0.00003 \\
(0.000007)\end{array}$ \\
\hline Divorced & $\begin{array}{r}0.084 \\
(0.012)\end{array}$ & $\begin{array}{r}0.081 \\
(0.011)\end{array}$ & $\begin{array}{r}0.106 \\
(0.011)\end{array}$ \\
\hline Married & $\begin{array}{r}0.050 \\
(0.006)\end{array}$ & $\begin{array}{r}0.051 \\
(0.006)\end{array}$ & $\begin{array}{r}0.043 \\
(0.006)\end{array}$ \\
\hline Separated & $\begin{array}{r}0.034 \\
(0.042)\end{array}$ & $\begin{array}{r}0.033 \\
(0.042)\end{array}$ & $\begin{array}{r}0.042 \\
(0.043)\end{array}$ \\
\hline Widow & $\begin{array}{r}0.008 \\
(0.006)\end{array}$ & $\begin{array}{r}0.006 \\
(0.006)\end{array}$ & $\begin{array}{r}0.017 \\
(0.006)\end{array}$ \\
\hline Male & $\begin{array}{r}0.020 \\
(0.003)\end{array}$ & $\begin{array}{r}0.020 \\
(0.003)\end{array}$ & $\begin{array}{r}0.020 \\
(0.003)\end{array}$ \\
\hline Testate & $\begin{array}{r}0.242 \\
(0.006)\end{array}$ & $\begin{array}{r}0.241 \\
(0.006)\end{array}$ & $\begin{array}{r}0.245 \\
(0.006)\end{array}$ \\
\hline Married in a CP state & $\begin{array}{r}-0.026 \\
(0.005)\end{array}$ & $\begin{array}{r}-0.026 \\
(0.005)\end{array}$ & $\begin{array}{r}-0.029 \\
(0.005)\end{array}$ \\
\hline Widow in a CP state & $\begin{array}{r}-0.029 \\
(0.006)\end{array}$ & $\begin{array}{r}-0.030 \\
(0.006)\end{array}$ & $\begin{array}{r}-0.025 \\
(0.006)\end{array}$ \\
\hline log real S\&P 500 & $\begin{array}{r}0.258 \\
(0.009) \\
\end{array}$ & $\begin{array}{r}0.259 \\
(0.009)\end{array}$ & $\begin{array}{r}0.248 \\
(0.009) \\
\end{array}$ \\
\hline $\begin{array}{l}\text { log real S\&P } 500, \\
5 \text { year lag }\end{array}$ & $\begin{array}{r}-0.033 \\
(0.006)\end{array}$ & $\begin{array}{r}-0.033 \\
(0.006)\end{array}$ & $\begin{array}{r}-0.028 \\
(0.006)\end{array}$ \\
\hline $\begin{array}{l}\text { log real S\&P 500, } \\
10 \text { year lag }\end{array}$ & $\begin{array}{r}-0.036 \\
(0.006) \\
\end{array}$ & $\begin{array}{r}-0.037 \\
(0.006)\end{array}$ & $\begin{array}{r}-0.029 \\
(0.006) \\
\end{array}$ \\
\hline $\begin{array}{l}\text { log real S\&P } 500, \\
\text { at age } 45\end{array}$ & $\begin{array}{r}0.014 \\
(0.005)\end{array}$ & $\begin{array}{r}0.014 \\
(0.005)\end{array}$ & $\begin{array}{r}0.015 \\
(0.005)\end{array}$ \\
\hline $\begin{array}{l}\text { log inequality } \\
\text { (10 year lag) }\end{array}$ & $\begin{array}{r}-0.219 \\
(0.035)\end{array}$ & $\begin{array}{r}-0.229 \\
(0.033)\end{array}$ & $\begin{array}{r}-0.148 \\
(0.031)\end{array}$ \\
\hline $\begin{array}{l}\text { log real aggregate } \\
\text { wealth per capita }\end{array}$ & $\begin{array}{r}0.531 \\
(0.036)\end{array}$ & $\begin{array}{r}0.538 \\
(0.035)\end{array}$ & $\begin{array}{r}0.485 \\
(0.034)\end{array}$ \\
\hline log death rate & $\begin{array}{r}0.001 \\
(0.089)\end{array}$ & $\begin{array}{r}-0.021 \\
(0.085)\end{array}$ & $\begin{array}{r}0.147 \\
(0.082)\end{array}$ \\
\hline time trend & $\begin{array}{r}-0.005 \\
(0.001)\end{array}$ & $\begin{array}{r}-0.006 \\
(0.001)\end{array}$ & $\begin{array}{r}-0.002 \\
(0.001)\end{array}$ \\
\hline constant & $\begin{array}{r}7.889 \\
(0.347)\end{array}$ & $\begin{array}{r}7.926 \\
(0.343)\end{array}$ & $\begin{array}{r}7.638 \\
(0.347)\end{array}$ \\
\hline $\bar{R}^{2}$ & 0.1637 & 0.1644 & 0.1592 \\
\hline$N$ & 242,897 & 242,897 & 242,897 \\
\hline
\end{tabular}

Notes:

The dependent variable is the logarithm of net worth in 1945 dollars.

Standard errors are in parentheses.

In the regressions, we also controlled for age imputation dummy, imputed age, imputed age square, and S\&P 500 at age of 45 interacted with the age imputation dummy.

The three tax measures described in Table 2 are used as instruments in specification I. The ten year lagged values and the values at age 45 are added in specification II. In specification III, dummies for married and widowed individuals dying in years when the limited marital deduction was available (1948-1981) and when the unlimited marital deduction was available (post 1981) are also included. 
Table 4: Pooled Cross-Section Regression Results: Interactions with the Tax Rate

\begin{tabular}{|c|c|c|c|c|}
\hline Independent Variable & $\mathrm{I}$ & II & III & IV \\
\hline log (1-RATE) & $\begin{array}{r}0.072 \\
(0.024)\end{array}$ & $\begin{array}{r}0.033 \\
(0.024)\end{array}$ & $\begin{array}{r}-0.048 \\
(0.058)\end{array}$ & $\begin{aligned}-0.053 \\
(0.036)\end{aligned}$ \\
\hline Male*log (1-RATE) & $\begin{array}{r}0.012 \\
(0.015)\end{array}$ & & & \\
\hline Married*log (1-RATE) & & $\begin{array}{r}-0.0788 \\
(0.0193)\end{array}$ & & \\
\hline Age*log (1-RATE) & & & $\begin{array}{r}0.0017 \\
(0.0007)\end{array}$ & \\
\hline Testate*log (1-RATE) & & & & $\begin{array}{r}0.162 \\
(0.031)\end{array}$ \\
\hline $\begin{array}{l}\text { max log ( } 1 \text {-income tax } \\
\text { rate) (10 year lag) }\end{array}$ & $\begin{array}{r}-0.061 \\
(0.006)\end{array}$ & $\begin{array}{r}-0.052 \\
(0.006)\end{array}$ & $\begin{array}{r}-0.059 \\
(0.006)\end{array}$ & $\begin{array}{r}-0.061 \\
(0.006)\end{array}$ \\
\hline $\begin{array}{l}\text { max log }(1 \text {-corporate } \\
\text { tax rate) }(10 \text { year lag })\end{array}$ & $\begin{array}{r}0.211 \\
(0.039) \\
\end{array}$ & $\begin{array}{r}0.210 \\
(0.039) \\
\end{array}$ & $\begin{array}{r}0.217 \\
(0.039) \\
\end{array}$ & $\begin{array}{r}0.211 \\
(0.039)\end{array}$ \\
\hline $\begin{array}{l}\text { max log (1-income tax } \\
\text { rate) (at age } 45)\end{array}$ & $\begin{array}{r}0.062 \\
(0.019) \\
\end{array}$ & $\begin{array}{r}-0.005 \\
(0.004)\end{array}$ & $\begin{array}{r}-0.010 \\
(0.005)\end{array}$ & $\begin{array}{r}-0.008 \\
(0.004)\end{array}$ \\
\hline $\begin{array}{l}\text { max log (1-corporate } \\
\text { tax rate) (at age } 45 \text { ) }\end{array}$ & $\begin{array}{r}-0.007 \\
(0.004)\end{array}$ & $\begin{array}{r}0.066 \\
(0.019)\end{array}$ & $\begin{array}{r}0.076 \\
(0.020)\end{array}$ & $\begin{array}{r}0.064 \\
(0.019)\end{array}$ \\
\hline Age & $\begin{array}{r}-0.001 \\
(0.001)\end{array}$ & $\begin{array}{r}-0.001 \\
(0.001)\end{array}$ & $\begin{array}{r}-0.001 \\
(0.001)\end{array}$ & $\begin{array}{r}-0.001 \\
(0.001)\end{array}$ \\
\hline Age2 & $\begin{array}{r}0.00003 \\
(0.000007)\end{array}$ & $\begin{array}{r}0.00003 \\
(0.000007)\end{array}$ & $\begin{array}{r}0.00003 \\
(0.000007)\end{array}$ & $\begin{array}{r}0.00003 \\
(0.000007)\end{array}$ \\
\hline Divorced & $\begin{array}{r}0.104 \\
(0.011)\end{array}$ & $\begin{array}{r}0.104 \\
(0.011)\end{array}$ & $\begin{array}{r}0.103 \\
(0.011)\end{array}$ & $\begin{array}{r}0.108 \\
(0.011)\end{array}$ \\
\hline Married & $\begin{array}{r}0.043 \\
(0.006)\end{array}$ & $\begin{array}{r}0.024 \\
(0.007)\end{array}$ & $\begin{array}{r}0.045 \\
(0.006)\end{array}$ & $\begin{array}{r}0.044 \\
(0.006)\end{array}$ \\
\hline Separated & $\begin{array}{r}0.041 \\
(0.043)\end{array}$ & $\begin{array}{r}0.040 \\
(0.043)\end{array}$ & $\begin{array}{r}0.042 \\
(0.043)\end{array}$ & $\begin{array}{r}0.043 \\
(0.043)\end{array}$ \\
\hline Widow & $\begin{array}{r}0.016 \\
(0.006) \\
\end{array}$ & $\begin{array}{r}0.016 \\
(0.006)\end{array}$ & $\begin{array}{r}0.017 \\
(0.006) \\
\end{array}$ & $\begin{array}{r}0.019 \\
(0.006)\end{array}$ \\
\hline Male & $\begin{array}{r}0.024 \\
(0.006)\end{array}$ & $\begin{array}{r}0.020 \\
(0.003)\end{array}$ & $\begin{array}{r}0.019 \\
(0.003)\end{array}$ & $\begin{array}{r}0.019 \\
(0.003)\end{array}$ \\
\hline Testate & $\begin{array}{r}0.245 \\
(0.006)\end{array}$ & $\begin{array}{r}0.243 \\
(0.006)\end{array}$ & $\begin{array}{r}0.245 \\
(0.006)\end{array}$ & $\begin{array}{r}0.278 \\
(0.009)\end{array}$ \\
\hline Married in a CP state & $\begin{array}{r}-0.029 \\
(0.005)\end{array}$ & $\begin{array}{r}-0.030 \\
(0.005)\end{array}$ & $\begin{array}{r}-0.029 \\
(0.005)\end{array}$ & $\begin{array}{r}-0.029 \\
(0.005)\end{array}$ \\
\hline Widow in a CP state & $\begin{array}{r}-0.026 \\
(0.006)\end{array}$ & $\begin{array}{r}-0.025 \\
(0.006)\end{array}$ & $\begin{array}{l}-0.025 \\
(0.006)\end{array}$ & $\begin{array}{r}-0.025 \\
(0.006)\end{array}$ \\
\hline log real S\&P 500 & $\begin{array}{r}0.249 \\
(0.009)\end{array}$ & $\begin{array}{r}0.254 \\
(0.009)\end{array}$ & $\begin{array}{r}0.251 \\
(0.009)\end{array}$ & $\begin{array}{r}0.247 \\
(0.009)\end{array}$ \\
\hline $\begin{array}{l}\text { log real S\&P } 500, \\
5 \text { year lag }\end{array}$ & $\begin{array}{r}-0.029 \\
(0.006)\end{array}$ & $\begin{array}{r}-0.032 \\
(0.006)\end{array}$ & $\begin{array}{r}-0.029 \\
(0.006)\end{array}$ & $\begin{array}{r}-0.028 \\
(0.006)\end{array}$ \\
\hline $\begin{array}{l}\text { log real S\&P 500, } \\
10 \text { year lag }\end{array}$ & $\begin{array}{r}-0.030 \\
(0.006)\end{array}$ & $\begin{array}{r}-0.035 \\
(0.006)\end{array}$ & $\begin{array}{r}-0.031 \\
(0.006)\end{array}$ & $\begin{array}{r}-0.029 \\
(0.006)\end{array}$ \\
\hline $\begin{array}{l}\text { log real S\&P } 500, \\
\text { at age } 45\end{array}$ & $\begin{array}{r}0.015 \\
(0.005)\end{array}$ & $\begin{array}{r}0.014 \\
(0.005)\end{array}$ & $\begin{array}{r}0.014 \\
(0.005)\end{array}$ & $\begin{array}{r}0.015 \\
(0.005)\end{array}$ \\
\hline $\begin{array}{l}\text { log inequality } \\
\text { (10 year lag) }\end{array}$ & $\begin{array}{r}-0.152 \\
(0.031)\end{array}$ & $\begin{array}{l}-0.195 \\
(0.032)\end{array}$ & $\begin{array}{r}-0.163 \\
(0.031)\end{array}$ & $\begin{array}{r}-0.153 \\
(0.031)\end{array}$ \\
\hline $\begin{array}{l}\text { log real aggregate } \\
\text { wealth per capita }\end{array}$ & $\begin{array}{r}0.488 \\
(0.034)\end{array}$ & $\begin{array}{r}0.518 \\
(0.035)\end{array}$ & $\begin{array}{r}0.496 \\
(0.034)\end{array}$ & $\begin{array}{r}0.490 \\
(0.034)\end{array}$ \\
\hline log death rate & $\begin{array}{r}0.136 \\
(0.082)\end{array}$ & $\begin{array}{r}0.060 \\
(0.083)\end{array}$ & $\begin{array}{r}0.125 \\
(0.082)\end{array}$ & $\begin{array}{r}0.148 \\
(0.082)\end{array}$ \\
\hline time trend & $\begin{array}{r}-0.002 \\
(0.001)\end{array}$ & $\begin{array}{r}-0.004 \\
(0.001)\end{array}$ & $\begin{array}{r}-0.002 \\
(0.001)\end{array}$ & $\begin{array}{r}-0.002 \\
(0.001)\end{array}$ \\
\hline constant & $\begin{array}{r}7.658 \\
(0.346) \\
\end{array}$ & $\begin{array}{r}7.792 \\
(0.344) \\
\end{array}$ & $\begin{array}{r}7.638 \\
(0.346) \\
\end{array}$ & $\begin{array}{r}7.584 \\
(0.347) \\
\end{array}$ \\
\hline $\bar{R}^{2}$ & 0.1596 & 0.1619 & 0.1597 & 0.1591 \\
\hline$N$ & 242,897 & 242,897 & 242,897 & 242,897 \\
\hline
\end{tabular}

Notes:

The dependent variable is the logarithm of net worth in 1945 dollars.

Standard errors are in parentheses.

In the regressions, we also controlled for age imputation dummy, imputed age, imputed age square, and S\&P 500 at age of 45 interacted with the age imputation dummy.

The set of instruments includes all the ones listed in the notes to Table 3, and, additionally, all these instruments interacted with the variable analyzed in a given specification. 
Table 5: Pooled Cross-Section Regression Results: Alternative Measures of the Tax Rate

\begin{tabular}{|c|c|c|c|}
\hline Independent Variable & I & II & III \\
\hline log (1-RATE45) & $\begin{array}{r}0.160 \\
(0.038)\end{array}$ & & \\
\hline $\log (1-$ RATE10) & & $\begin{array}{r}0.100 \\
(0.029)\end{array}$ & \\
\hline $\log (1-R A T E M A X)$ & & & $\begin{aligned}-0.571 \\
(0.163)\end{aligned}$ \\
\hline $\begin{array}{l}\max \log (1-\text {-income } \\
\text { tax rate) }(10 \text { year lag })\end{array}$ & $\begin{array}{r}-0.052 \\
(0.006)\end{array}$ & $\begin{array}{r}-0.055 \\
(0.006)\end{array}$ & $\begin{array}{r}0.032 \\
(0.016)\end{array}$ \\
\hline $\begin{array}{l}\text { max log }(1 \text {-corporate } \\
\text { tax rate) }(10 \text { year lag })\end{array}$ & $\begin{array}{r}0.227 \\
(0.040)\end{array}$ & $\begin{array}{r}0.202 \\
(0.039)\end{array}$ & $\begin{array}{l}-0.245 \\
(0.240)\end{array}$ \\
\hline $\begin{array}{l}\text { max log (1-income tax } \\
\text { rate) (at age } 45)\end{array}$ & $\begin{array}{r}-0.004 \\
(0.004)\end{array}$ & $\begin{array}{r}-0.007 \\
(0.004)\end{array}$ & $\begin{array}{r}-0.004 \\
(0.005)\end{array}$ \\
\hline $\begin{array}{l}\text { max log (1-corporate } \\
\text { tax rate) (at age } 45 \text { ) }\end{array}$ & $\begin{array}{r}0.009 \\
(0.022)\end{array}$ & $\begin{array}{r}0.060 \\
(0.019)\end{array}$ & $\begin{array}{r}0.039 \\
(0.024)\end{array}$ \\
\hline Age & $\begin{array}{r}-0.001 \\
(0.001)\end{array}$ & $\begin{array}{l}-0.001 \\
(0.001)\end{array}$ & $\begin{array}{r}-0.003 \\
(0.001)\end{array}$ \\
\hline Age2 & $\begin{array}{r}0.00002 \\
(0.000007)\end{array}$ & $\begin{array}{r}0.00003 \\
(0.000007)\end{array}$ & $\begin{array}{r}0.00004 \\
(0.000010)\end{array}$ \\
\hline Divorced & $\begin{array}{r}0.107 \\
(0.011)\end{array}$ & $\begin{array}{r}0.105 \\
(0.011)\end{array}$ & $\begin{array}{r}0.075 \\
(0.022)\end{array}$ \\
\hline Married & $\begin{array}{r}0.041 \\
(0.006)\end{array}$ & $\begin{array}{r}0.043 \\
(0.006)\end{array}$ & $\begin{array}{r}0.041 \\
(0.018)\end{array}$ \\
\hline Separated & $\begin{array}{r}0.041 \\
(0.043)\end{array}$ & $\begin{array}{r}0.041 \\
(0.043)\end{array}$ & $\begin{array}{r}0.004 \\
(0.078)\end{array}$ \\
\hline Widow & $\begin{array}{r}0.016 \\
(0.006)\end{array}$ & $\begin{array}{r}0.017 \\
(0.006)\end{array}$ & $\begin{array}{r}-0.007 \\
(0.020)\end{array}$ \\
\hline Male & $\begin{array}{r}0.020 \\
(0.003)\end{array}$ & $\begin{array}{r}0.019 \\
(0.003)\end{array}$ & $\begin{array}{r}0.015 \\
(0.005)\end{array}$ \\
\hline Testate & $\begin{array}{r}0.245 \\
(0.006)\end{array}$ & $\begin{array}{r}0.245 \\
(0.006)\end{array}$ & $\begin{array}{r}0.182 \\
(0.013)\end{array}$ \\
\hline Married in a CP state & $\begin{array}{r}-0.029 \\
(0.005)\end{array}$ & $\begin{array}{r}-0.029 \\
(0.005)\end{array}$ & $\begin{array}{l}-0.003 \\
(0.006)\end{array}$ \\
\hline Widow in a CP state & $\begin{array}{r}-0.026 \\
(0.006)\end{array}$ & $\begin{array}{r}-0.025 \\
(0.006)\end{array}$ & $\begin{array}{r}-0.004 \\
(0.008)\end{array}$ \\
\hline log real S\&P 500 & $\begin{array}{r}0.256 \\
(0.008)\end{array}$ & $\begin{array}{r}0.257 \\
(0.009)\end{array}$ & $\begin{array}{r}0.151 \\
(0.024)\end{array}$ \\
\hline $\begin{array}{l}\text { log real S\&P } 500, \\
5 \text { year lag }\end{array}$ & $\begin{array}{r}-0.027 \\
(0.006)\end{array}$ & $\begin{array}{r}-0.029 \\
(0.006)\end{array}$ & $\begin{array}{r}0.019 \\
(0.013)\end{array}$ \\
\hline $\begin{array}{l}\text { log real S\&P 500, } \\
10 \text { year lag }\end{array}$ & $\begin{array}{r}-0.035 \\
(0.006)\end{array}$ & $\begin{array}{l}-0.038 \\
(0.006)\end{array}$ & $\begin{array}{l}-0.085 \\
(0.012)\end{array}$ \\
\hline $\begin{array}{l}\text { log real S\&P } 500, \\
\text { at age } 45\end{array}$ & $\begin{array}{r}0.009 \\
(0.006)\end{array}$ & $\begin{array}{r}0.015 \\
(0.005)\end{array}$ & $\begin{array}{r}0.008 \\
(0.007)\end{array}$ \\
\hline log inequality (10 year lag) & $\begin{array}{r}-0.192 \\
(0.029)\end{array}$ & $\begin{array}{l}-0.207 \\
(0.030)\end{array}$ & $\begin{array}{l}-0.083 \\
(0.094)\end{array}$ \\
\hline $\begin{array}{l}\text { log real aggregate } \\
\text { wealth per capita }\end{array}$ & $\begin{array}{r}0.542 \\
(0.035)\end{array}$ & $\begin{array}{r}0.517 \\
(0.034)\end{array}$ & $\begin{array}{r}0.947 \\
(0.074)\end{array}$ \\
\hline log death rate & $\begin{array}{r}0.088 \\
(0.080)\end{array}$ & $\begin{array}{r}0.083 \\
(0.080)\end{array}$ & $\begin{array}{r}0.641 \\
(0.203)\end{array}$ \\
\hline time trend & $\begin{array}{r}-0.004 \\
(0.001)\end{array}$ & $\begin{array}{c}-0.003 \\
(0.001)\end{array}$ & $\begin{array}{c}-0.018 \\
(0.003)\end{array}$ \\
\hline constant & $\begin{array}{r}7.514 \\
(0.350) \\
\end{array}$ & $\begin{array}{r}7.749 \\
(0.345) \\
\end{array}$ & $\begin{array}{r}3.183 \\
(0.776) \\
\end{array}$ \\
\hline $\bar{R}^{2}$ & 0.1593 & 0.1593 & 0.0395 \\
\hline$N$ & 242,897 & 242,897 & 95,611 \\
\hline
\end{tabular}

Notes:

The dependent variable is the logarithm of net worth in 1945 dollars.

Standard errors are in parentheses.

In the regressions, we also controlled for age imputation dummy, imputed age, imputed age square, and S\&P 500 at age of 45 interacted with the age imputation dummy.

The set of instruments includes all the ones listed in the notes to Table 3. 
Figure 1: Simulated Wealth Over a Lifetime Under the Current Estate Tax and under a Zero-Tax Regime

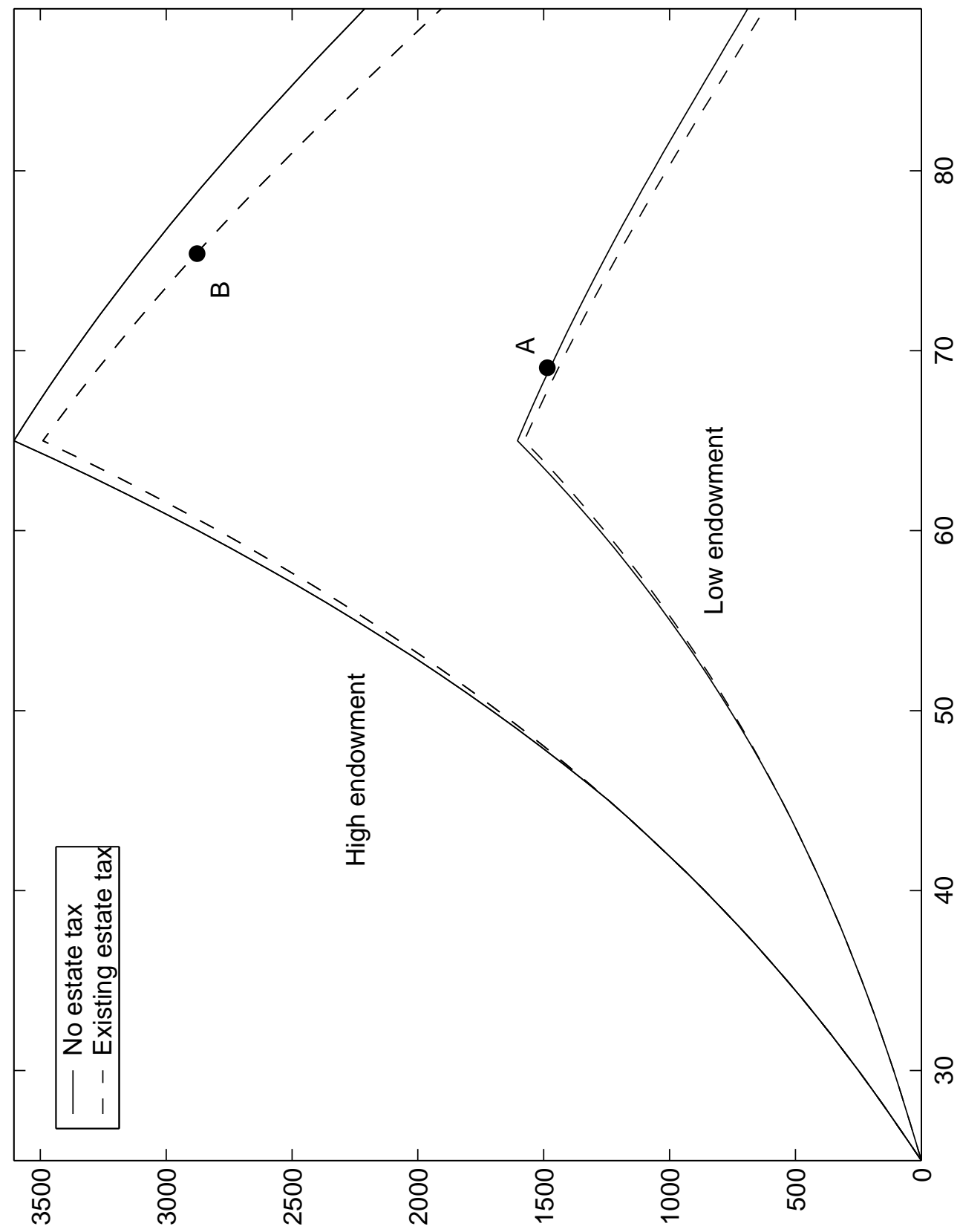


Figure 2: Simulated Consumption Over a Lifetime Under the Current Estate Tax and under a Zero-Tax Regime

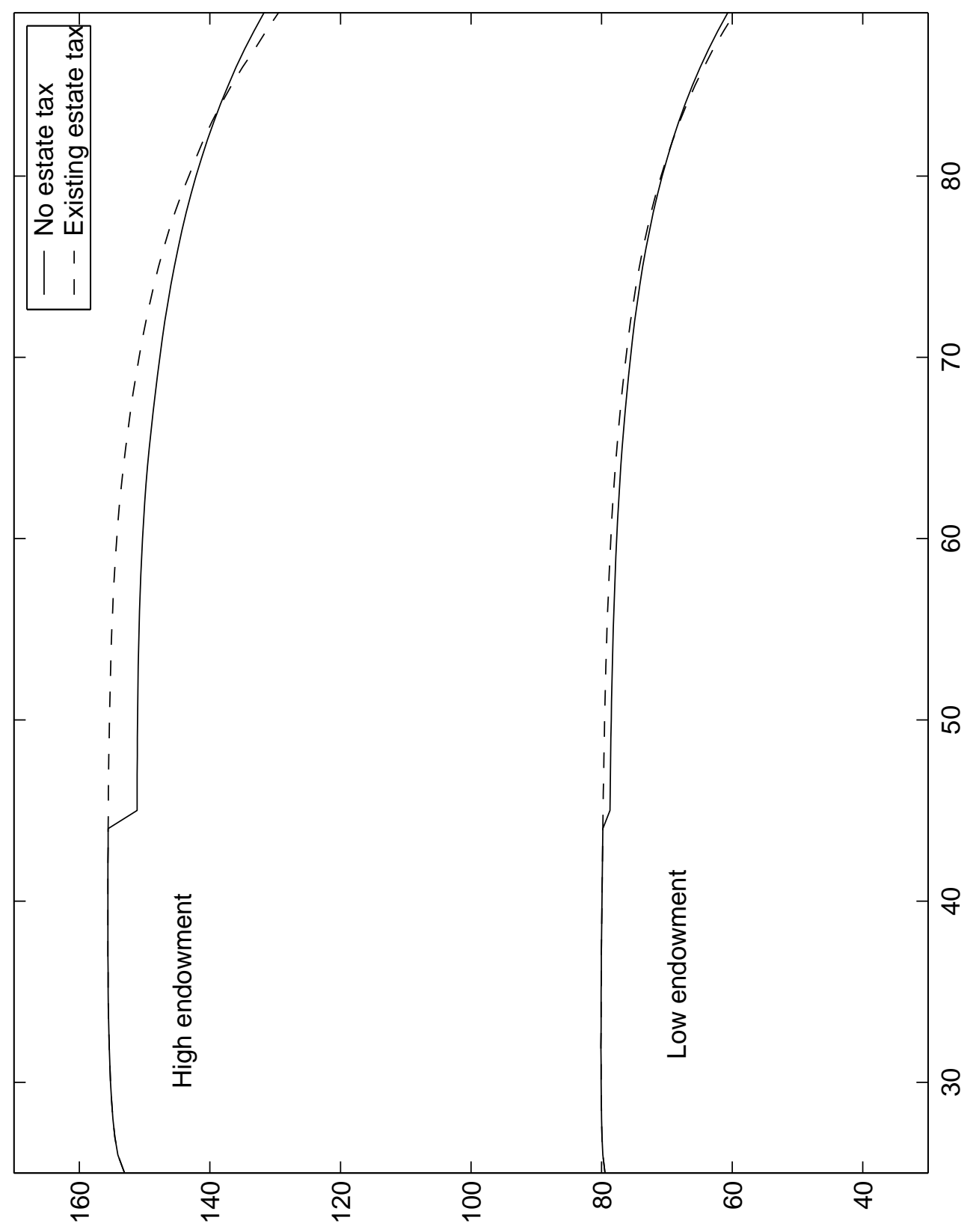


Figure 3: Top estate tax rate (TTAX) and the estate/wealth ratio

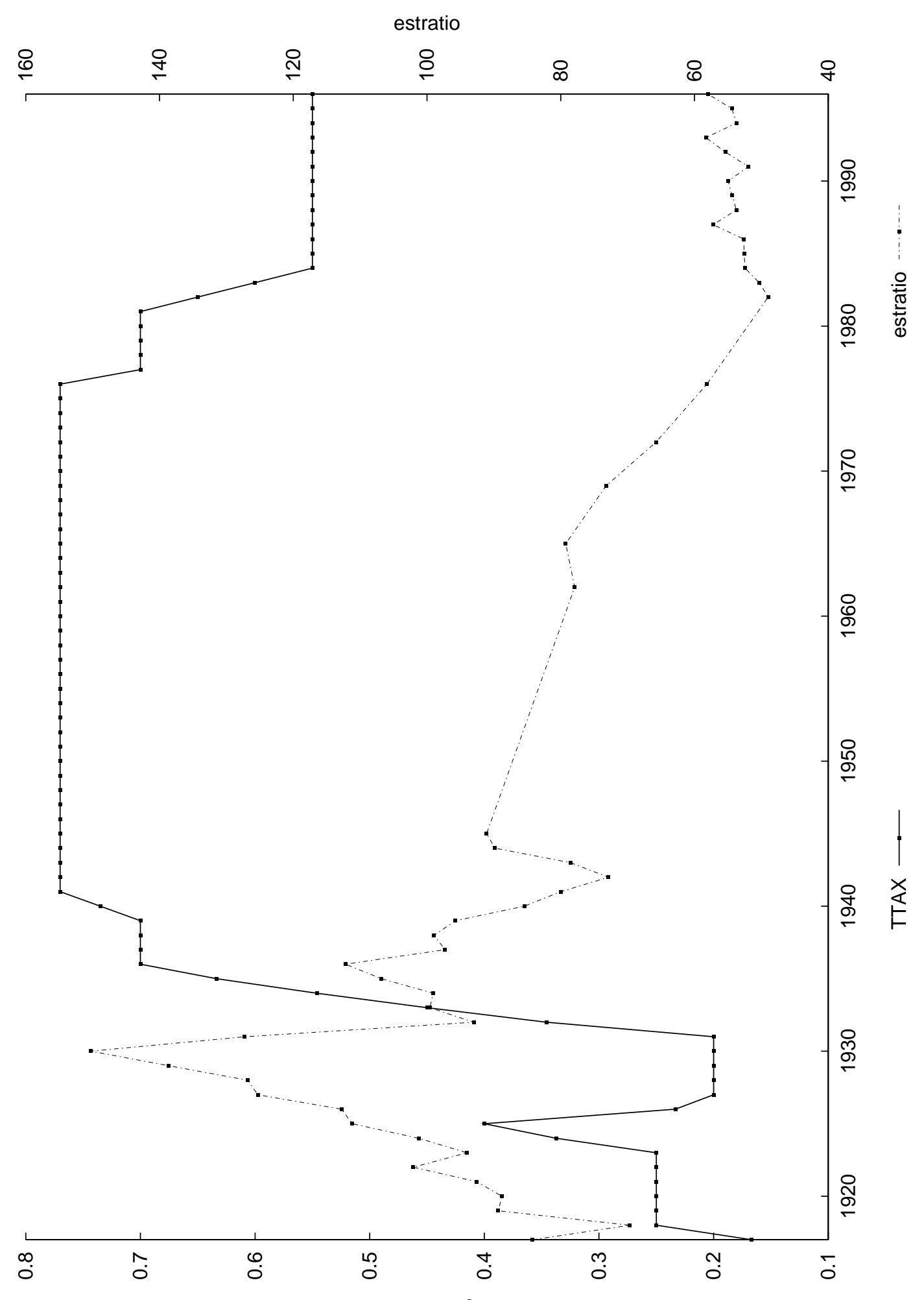


Figure 4: Estate tax rate at 100 times average wealth (T100) and the estate/wealth ratio

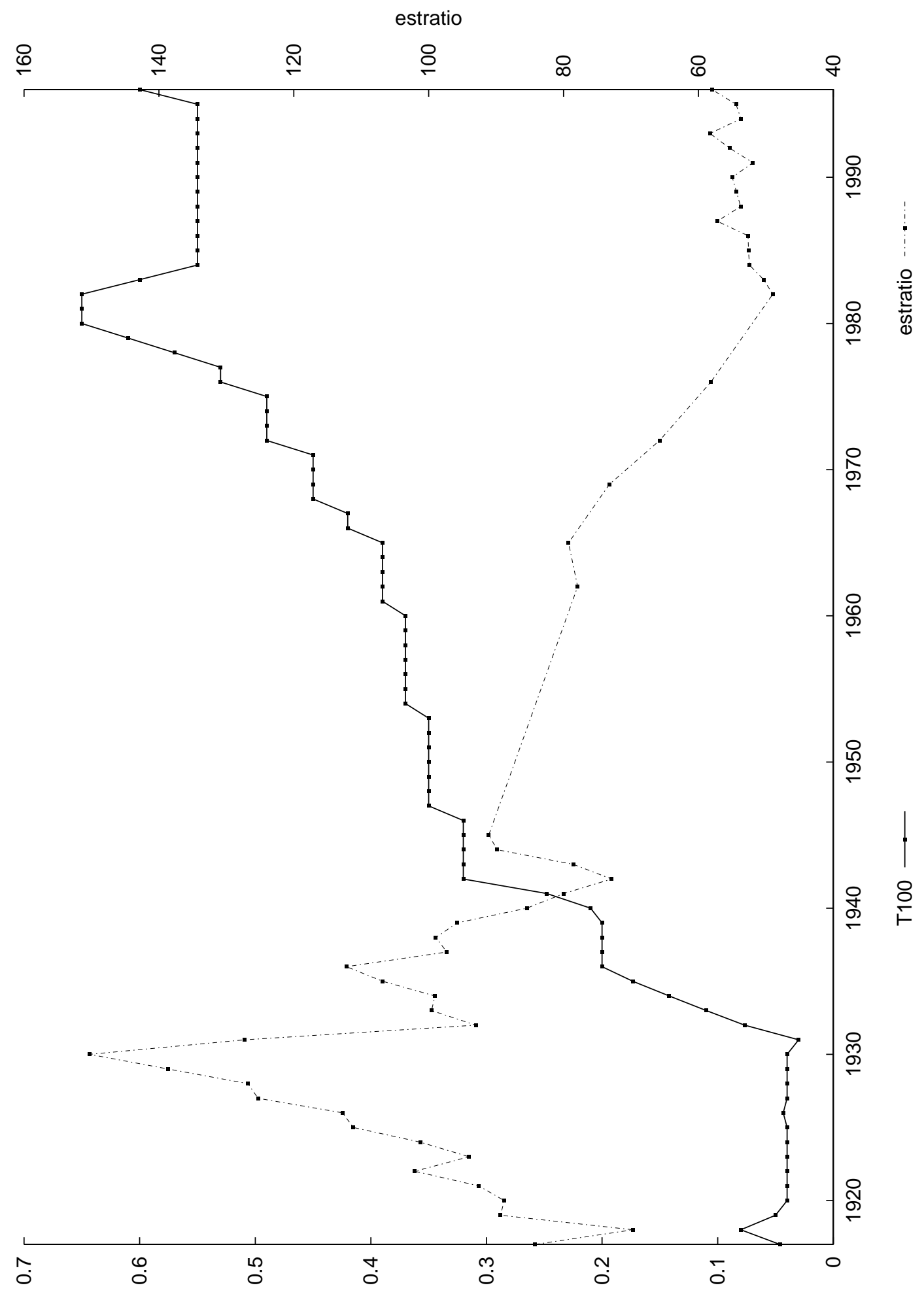


Figure 5: Estate tax rate at 40 times average wealth (T40) and the estate/wealth ratio

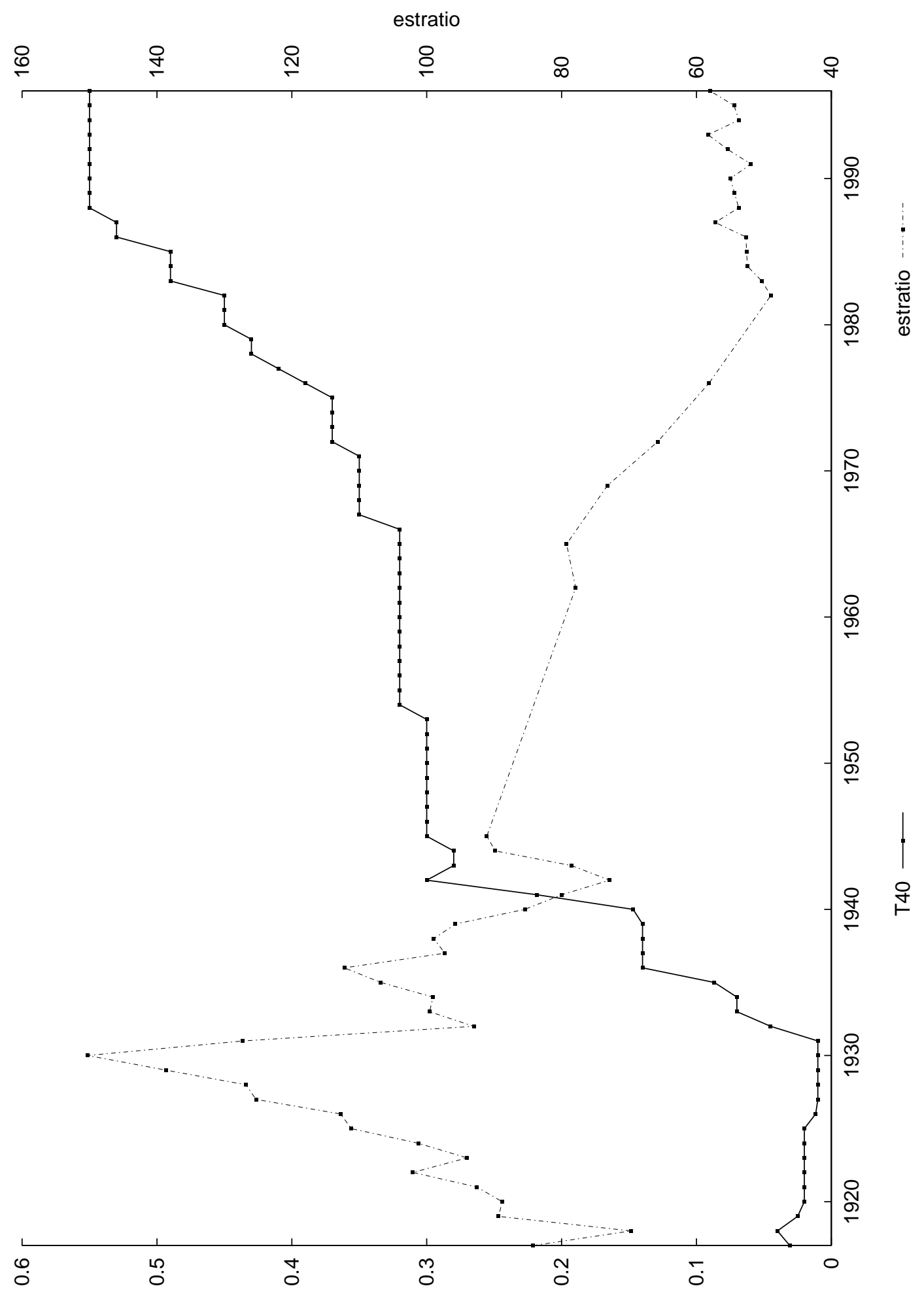

